\title{
Rana Plaza collapse aftermath: are CSR compliance and auditing pressures effective?
}

\author{
Noemi Sinkovics and Samia Ferdous Hoque \\ Alliance Manchester Business School, The University of Manchester, \\ Manchester, UK, and \\ Rudolf R. Sinkovics \\ Alliance Manchester Business School, \\ The University of Manchester, Manchester, UK and \\ Lappeenranta University of Technology, Lappeenranta, Finland
}

Rana Plaza collapse aftermath

\begin{abstract}
Purpose - The purpose of this paper is to investigate the intended and unintended consequences of compliance and auditing pressures in the Bangladeshi garment industry. To explore this issue the authors draw on three medium-sized suppliers. The institutional changes that followed the Rana Plaza accident in April 2013 make Bangladesh in general and the garment industry in particular an interesting and suitable research setting for standards compliance.

Design/methodology/approach - The study adopts a multiple case study approach. Face-to-face interviews have been conducted with the owners of three Bangladeshi garment manufacturing firms and several workers. Additionally, organisational documents and local newspaper articles had been collected wherever possible.

Findings - The results indicate that the pressure for compliance has led the case companies to prioritise the implementation of measurable standards over the socially grounded needs and priorities of workers. As a consequence certain initiatives instead of adding new social value in fact destroyed previously existing social value. Furthermore, the pressure for compliance created the necessity to find ways to cover the sizable cost of compliance. This prompted firms to pursue process upgrading through technological advancements and increased work pressures on the labour force. These initiatives led to an increased power imbalance and the exclusion of unskilled workers from the job market.

Research limitations/implications - The paper contributes to the understanding of the human rights implications of compliance and auditing pressures and initiatives. Furthermore, in order to further enrich existing knowledge in the critical accounting literature, the study draws on insights from the global value chains (GVC) and international business (IB) literatures.

Originality/value - The paper contributes to the understanding of the human rights implications of compliance and auditing pressures and initiatives. Furthermore, in order to further enrich existing knowledge in the critical accounting literature, the study draws on insights from the GVC and IB literatures.
\end{abstract}

Keywords Global value chains, Human rights, Social value, Social upgrading, CSR compliance Paper type Research paper

(C) Sinkovics, Hoque and Sinkovics

Published by Emerald Group Publishing Limited. This article is published under the Creative Commons Attribution (CC BY 3.0) licence. Anyone may reproduce, distribute, translate and create derivative works of this article (for both commercial and non-commercial purposes), subject to full attribution to the original publication and authors. The full terms of this licence may be seen at http://creativecommons.org/licences/by/3.0/legalcode

Financial support from the Economic and Social Research Council (ESRC), UK, who funded part of Rudolf Sinkovics' time (grant number RES-075-25-0028), is gratefully acknowledged.

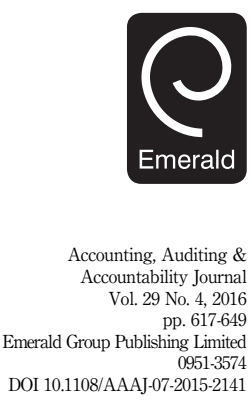


AAAJ

29,4

618

\section{Introduction}

The last three or four decades have seen the development of an interdisciplinary accounting research movement with the aim of providing an alternative to prevalent functionalistic-positivistic and mostly desk-based statistical studies (Parker and Guthrie, 2014). This alternative research agenda aims at drawing attention to the fact that accounting is both a technical and a social practice. As a technical method, it involves routines and procedures geared towards the recording, measuring, and interpreting of specific data. As a social practice, it has implications for individuals' behaviour. The technical practice produces an array of intended as well as unintended consequences beyond the organisation that employs that practice (Carnegie, 2014). In recent years, an increasing number of calls have been made from within the interdisciplinary accounting research community for more attention to be paid to the broader societal context and the consequences of accounting practices (Guthrie and Parker, 2014). However, in order to achieve a deeper and richer understanding of these contextual issues as well as the intended and unintended consequences of accounting and auditing practices, researchers need "to develop and be open to a wider range of methodologies, theoretical perspectives, data sources and disciplinary traditions" (Guthrie and Parker, 2014, p. 7). The present paper contributes to this overall agenda by introducing insights from the global value chain (GVC) and international business (IB) literatures to further explore and enrich existing knowledge within the critical accounting field.

Owen (2008), reflecting on the state and future of social and environmental accounting research, points to the need to take on a broader stakeholder approach and Accord more attention to power asymmetries and worker-/employee-related issues. Furthermore, he calls for more field-based research employing techniques such as action research, interviews, and case studies. Humphrey and Scapens (1996) suggest that, by placing the case in the centre of the research process, rather than specific theories, accounting research can move away from simply applying borrowed theories towards more problem-driven investigations. This does not mean that researchers should not use theories to inform their case study research. Rather, the imported insights serve, if appropriate, as an initial framework for further theorising (Eisenhardt, 1989; Sinkovics et al., 2014). Furthermore, Brennan and Solomon (2008) advocate a broader sectoral analysis, the consideration of a wider range of accountability mechanisms, and a greater focus on developing economies.

We are positioning our study against this background and embark on a case-based exploration of the intended and unintended consequences of compliance and auditing pressures for small Bangladeshi manufacturers in general, and for their workers' socioeconomic and cultural human rights in particular. We do so by drawing on literature from other disciplines to create an initial analytical framework. However, we adopt a more grassroots (cf. Goldewijk and De Gaay Fortman, 1999; Sen, 2004) as opposed to traditional approach to human rights. The latter tends to focus predominantly on statecitizen relationships and thus mostly excludes non-state actors from bearing responsibility (cf. Gallhofer et al., 2011). A more extensive elaboration of the approach followed in this study will be provided in the next section. Our case companies, although regularly audited, do not engage in report writing. Thus, in order to carry out the research, we conducted interviews with owners/managers and workers. Additionally, we collected organisational documents and drew on information from available secondary sources.

We chose Bangladesh as the context for our study because the heightened pressures for compliance following the Rana Plaza accident in April 2013 make it a suitable 
environment in which to examine the intended and unintended consequences of compliance and auditing pressures. The garment industry holds a paradoxical role in this country as it is both a heavy contributor to the country's economic development and seen as a potential obstacle to its future development (Belal et al., 2015). It thus makes for an interesting study setting from a GVC perspective. Our chosen case companies further represent $\mathrm{a}$, to date, under-studied set of supplier firms in Bangladesh. They are not sub-contractors and at the same time their relationship with their multinational buyers cannot be described as direct strategic sourcing (cf. Labowitz and Baumann-Pauly, 2014) due to the absence of formal written contracts. Rather, the supplier-buyer relationships are based on the buyer's tacit promise to place future orders if the supplier fulfils the buyer's expectations in terms of quality, price, and corporate social responsibility (CSR) compliance. Hoque et al. (2016) use the term "tacit promissory contracting" to describe this specific type of relationship.

The findings of this study are in line with previous research from both the CSR and GVC literatures questioning the effectiveness of the compliance model (e.g. Locke, 2013). Moreover, the cases imply that, while CSR compliance may fulfil the intended purpose of social upgrading in terms of measurable standards such as workplace safety, it can simultaneously lead to the destruction of previously present social value and leave workers worse off than they were before. From an accountability perspective, the study findings further highlight the problematic nature of accountability in GVCs in which corporations assume the role of (surrogate) accountability holders (Rubenstein, 2007). At the same time, they have neither adequate knowledge of the local context nor the ability or will to shield workers and local communities from the unintended consequences of the "enforced" accountability practices. The exploratory nature of the study means that further research is warranted and would help to shed more light on this extraordinary phenomenon. This paper contributes to the body of knowledge in several disciplinary areas, including the critical accounting, CSR, GVC, $\mathrm{IB}$, and human rights literatures.

\section{From compliance to social value}

To date, most studies connected to social and environmental reporting in Bangladesh adopt a stakeholder perspective either on the social and environmental responsibility and reporting of corporations and/or of their subsidiaries (e.g. Belal and Roberts, 2010; Reinecke and Donaghey, 2015) or on managers' perceptions of what is expected of them by their stakeholders (e.g. Islam and Deegan, 2008). The common thread that explicitly or implicitly runs through these studies is the argument that there is a need for "surrogate accountability" in developing countries with weak institutions, high corruption levels, and the inability of governments to implement regulations (cf. Belal et al., 2015; Rubenstein, 2007). From this point of view, corporations and factory owners are characterised as "power wielders" who frequently violate laws, regulations, and agreements. Accountability holders such as workers and local communities are unable to prevent the breaches of laws and/or social norms due to significant power asymmetry and other disadvantaging factors such as extreme poverty and vulnerability, lack of education, etc. Against this context, surrogate account holders are better equipped to pressurise power wielders to do what is "right" (Rubenstein, 2007). Surrogates can take the form of governments, supra-national bodies, civil society organisations, or partnerships among corporations. Programmes such as the Accord on Fire and Building Safety (the Accord) and the Business Social Compliance Initiative (BSCI) in Bangladesh can be argued to be further examples (cf. Reinecke and Donaghey, 2015).
Rana Plaza collapse aftermath 
AAAJ

29,4

620

At the same time, while surrogate accountability is often an important and necessary step in the development of an economy that is characterised by great inequalities, the practice of accountability, standard or surrogate, arguably undermines the responsibility of those being asked to be accountable (McKernan, 2012; McKernan and McPhail, 2012). This is because it prioritises the monitoring and recording of what people do or are asked to do over the identification of the reasons behind people's actions. Put differently, accountability shifts the focus from the question of what is morally right to a technocratic practice (Joannides, 2012). Furthermore, any accountability regime needs to be defined by the following six dimensions: "who, to whom, about what, through what processes, by what standards and with what effect" (Mashaw, 2005, p. 17). In cases where accountability and auditing practices are externally imposed on developing country suppliers, the tension between transparency, and responsibility may be further intensified. This is because, by pressurising the suppliers to comply with codes or standards, one imposes on the corporation the role of surrogate accountability holder. However, given the distance between multinational enterprises (MNEs) and their suppliers (both geographical and psychic), the former most likely lack sufficient insights into the context-dependent socially grounded needs of the workers (cf. Belal and Roberts, 2010; Lund-Thomsen, 2008; Sinkovics et al., 2014).

Furthermore, while many developing country firms' first encounters with formalised CSR practices happen through actual or desired interaction with a multinational buyer (Gugler and Shi, 2009), this does not mean that these firms had not created some form of social value before then (Sinkovics et al., 2014; Sundar, 2013). It simply means that they may not have referred to these activities as CSR (cf. Sundar, 2013) and may not have drawn on surrogate accountability holders to legitimise their activities (cf. Belal and Roberts, 2010). Sinkovics et al. (2014) note that developing country businesses close to the "bottom of the pyramid" often create social value as an organic outcome of their business model as they themselves and their employees are part of the "social" for which value needs to be created. To do so, they do not need an outsider's mission. Rather, social value is created as a result of identifying and alleviating social and economic constraints faced by the community of which they form part (we refer to this as the internalisation or "absorption" of social and economic constraints within the business model). Furthermore, by default, indigenous firms tend to be in a better position to identify these constraints due to their local embeddedness and contextual knowledge (cf. London and Hart, 2011).

Moreover, small factory owners tend to suffer from power asymmetry vis-à-vis their multinational buyers (Hoque et al., 2016). As a consequence, while they can be regarded as more powerful than their workers and the connected wider communities, they are very often comparatively powerless as far as their corporate buyers are concerned. This introduces the question of how externally imposed, formalised compliance and auditing practices impact on firms' existing social value creation practices.

In order to be able to explore the power asymmetry dimension between corporations, their Bangladeshi suppliers, and factory workers in more depth, it is necessary to draw on the GVC and IB literatures. An integrated lens created through the combination of concepts from the accountability, economic and social upgrading, and social value creation literatures can be used to gain deeper insights into whether such initiatives impact on a wider range of human rights for workers (cf. Giuliani and Macchi, 2014). However, before we turn to the empirical investigation of the intended and unintended consequences of compliance and auditing pressures, it is important to present a brief but more detailed discussion of the concepts of social and economic upgrading and social value creation. 


\subsection{Social and economic upgrading}

Belal et al.'s (2015) study suggests that the current growth in Bangladesh's garment industry is mostly due to the fact that it involves a highly polluting manufacturing process. From this it follows that, in their quest for profit maximisation, MNCs are not only outsourcing their production but also the pollution and labour exploitation that is "necessary" to keep costs low. At the same time, the GVC literature suggests that - once connected to a GVC - it is possible for individual supplier firms, and even for entire industries within a country, to upgrade economically (Lee and Gereffi, 2015). That is, it is possible to increase the ability of a firm "to move to a more profitable and/or technologically sophisticated capital- and skill-intensive economic niche" (Gereffi, 1999, p. 51).

Economic upgrading generally happens through the improvement of products, processes, and functions (Gereffi et al., 2005). Product upgrading entails the introduction of more advanced products, often requiring better skills than the previously manufactured products. Process upgrading involves the increase of efficiency within the production process, often through the substitution of capital for labour. Functional upgrading refers to a change in the combination of activities performed to increase the value added (Humphrey and Schmitz, 2002). Gereffi and Frederick (2010) propose four functional upgrading trajectories. Cut, make, and trim (CMT) producers focus exclusively on the production and the assembly of imported inputs based on the buyer's specifications. Original equipment manufacturers (OEMs) take on a broader range of manufacturing-related functions in addition to production, such as the sourcing of materials. Original design manufacturers are, in addition, involved in pre-production processes such as design and R\&D. Original brand manufacturers additionally possess post-production capabilities and are fully able to develop products under their own brand names.

As a consequence of this possibility of upgrading economically and moving to a more profitable position, an important question arises: can economic upgrading yield positive results for workers, or put differently, can it lead to social upgrading (e.g. Pipkin, 2011; Zhu and Pickles, 2014)? Social upgrading is defined as the process of improvement of the rights and entitlements of workers, as social actors, which enhance the quality of their employment (Barrientos et al., 2011). Barrientos et al. (2011) furthermore specify that social upgrading has two components: measurable standards and enabling rights. Measurable standards are the more quantifiable aspects of employment, such as wages, working conditions, and working hours. Enabling rights deal with more sophisticated issues, such as discrimination, freedom of association, freedom of speech, and career development.

However, investigations show that the impact of social upgrading is rather unevenly distributed between different groups of workers, such as skilled and unskilled (e.g. Barrientos et al., 2011), regular and irregular (e.g. Barrientos and Kritzinger, 2004; Rossi, 2011), and male and female (e.g. Barrientos et al., 2005). Most suppliers tend to be reluctant to enable rights that challenge deeply embedded labour relations or social norms, hoping to avoid disruption to the production process. As a consequence, issues such as gender discrimination, freedom of speech, and workers' skills development are still mainly neglected. As a consequence, the focus tends to be on the implementation of measurable and more visible standards (Barrientos and Smith, 2007). Furthermore, Barrientos and Kritzinger (2004) and Rossi (2011) find that increased pressures regarding product quality and production efficiency, coupled with the pressure for cost reduction, can lead to an increased reliance on irregular in addition to regular workers.
Rana Plaza collapse aftermath 
AAAJ

29,4

622

It seems more likely that economic upgrading would have a negative impact on the former than the latter group (Barrientos et al., 2011).

In the Bangladeshi context, compliance often represents a "ticket" for GVC participation (cf. Labowitz and Baumann-Pauly, 2014). Previous upgrading studies seem to indicate that codes for labour practices are unlikely to challenge embedded labour relations, social discriminations, and other dominant social norms that underpin the production process (e.g. Barrientos and Smith, 2007). While these studies provide some insights into the impact of economic upgrading and code compliance on workers, more investigation is needed to understand the implications for a wider variety of human rights (cf. Giuliani and Macchi, 2014).

\subsection{Social value creation and social, economic, and cultural rights}

Belal et al. (2015) and Tschakert (2007) suggest that in order for more meaningful solutions to be created for the vulnerable they need to be at the centre of the investigation. This is in line with the reconceptualisation of social value creation by Sinkovics et al. (2015). They adopt a multiple systems view that allows for a more integrated and nuanced analysis of both societal problems and how business initiatives can best respond to them. A system can be defined generally as "a grouping of parts that operate together for a common purpose" (Forrester, 1968). For the purposes of this paper, two systems are of interest. The first is the supplier firm. The firm's business model is designed with the purpose of making money now and in the future (Goldratt, 1990). However, instead of placing too much emphasis on the profit motive, Sinkovics et al. (2015) and Sinkovics et al. (2014) regard the generation of revenue as a necessary condition for business survival rather than the single most important driving force behind the existence of a business organisation. The second system is made up of the workers and the wider community, having the common goal of making use of their social, economic, and cultural rights (cf. Sinkovics et al., 2015).

Placing these "second generation" rights into the centre of the investigation allows for a more grassroots and need-based approach to development (cf. Goldewijk and De Gaay Fortman, 1999; Todaro and Smith, 2015). This approach goes beyond a measurement of economic development based merely on GDP and "possession" (i.e. minimum wage, commodities, etc.), and looks at ways to achieve "the sustained elevation of an entire society and social system toward a 'better' or 'more humane' life" (cf. Todaro and Smith, 2015, p. 22). The aforementioned authors conceptualise such an alternative way of development as consisting of three core values, namely, sustenance, self-esteem, and freedom. Sustenance encompasses basic needs such as food, health, shelter, and protection. Self-esteem stands for the universal need for self-worth, self-respect, and dignity. Last but not least, the value of freedom stands for freedom from servitude and the ability to choose. This last dimension is in accordance with Sen's $(1999,2004)$ capability approach to human rights. Goldewijk and De Gaay Fortman (1999) advocate the expression of these universal needs in the language of human rights.

For this reason, in this paper the abovementioned universal human needs are tied to social, economic, and cultural rights. This is based on the argument that certain human needs are so critical that their existence in itself constitutes a violation of human dignity (Goldewijk and De Gaay Fortman, 1999). A purely rights-based approach generally presupposes the state's ability to create and enforce laws to protect those rights. However, in many developing countries, the state is not in a position to do so (cf. Rubenstein, 2007). As a consequence, the simple existence of these universal needs 
should result in a collective duty to protect the ensuing rights (Wettstein, 2012). However, as not all societal actors will possess equal means and capabilities to tackle these problems, Wettstein (2012) proposes a capability-based approach to remedial action.

Goldewijk and De Gaay Fortman (1999), furthermore, differentiate between expressed and felt needs. Subsistence needs belong to the expressed category. Felt needs, on the other hand, are less tangible and correspond to self-esteem and dignity issues as well as issues pertaining to the freedom to live a life that is perceived to have value (see, also Sen, 2004; Todaro and Smith, 2011). However, felt needs are not always expressed, due to prevalent power relationships, at times manifesting as abuse and oppression. Moreover, these felt needs may even be distorted and hidden by development agencies or other organisations that set out to provide support (Goldewijk and De Gaay Fortman, 1999). This distortion or obscuring of felt needs can happen due to resource scarcity, bureaucratic ignorance, or legitimacy-driven opportunism (Goldewijk and De Gaay Fortman, 1999; Scherer et al., 2013; Sethi, 1975). In cases where needs are distorted through bureaucratic, professionally constructed processes one can speak of "prescribed needs" (Goldewijk and De Gaay Fortman, 1999). This argument also holds in the case of compliance codes and other prescriptive accountability practices. As a consequence, it can be argued that both compliance and the social upgrading approaches are more likely to cater for measurable, prescribed needs than felt needs, and will have some negative implications for social, economic, and cultural human rights.

Against this background, a more flexible and bottom-up view that places the core values of development - expressed in the language of social, economic, and cultural rights - at the centre of the investigation can be argued to be a necessary complement for more top-down alternatives such as declarations, codes, and guiding principles (e.g. the UN guiding principles on business and human rights). This is also in line with calls for "accounterability" practices; that is, for bringing more dynamism, creativity, and the "unknown" into accounting, accountability, and auditing (cf. Kamuf, 2007; McKernan and McPhail, 2012). In addition to adopting a multi-system view to identify the relevant constraints for the business organisation as well as for the workers and the wider community, Sinkovics et al. (2015) draw attention to the difference between the alleviation of root causes of these constraints and the mere treatment of the symptoms of those root causes. They furthermore argue that, in order to make the most of the capability-based remedial action proposed by Wettstein (2012), actors need to develop the unique capability to differentiate between the symptoms and root causes of human rights violations. This is all the more important as many compliance mechanisms are argued to treat the symptoms of certain problems rather than their root causes (cf. Locke, 2013).

\section{Research methods}

As delineated in the introduction section, the present paper sets out to explore the intended and unintended consequences of compliance and auditing pressures for Bangladeshi garment manufacturers and their workers. Before we provide an overview of the study design, we would like to introduce the context in more detail. We chose the Bangladeshi garment industry as the setting for the study due to the heightened pressures for compliance following the Rana Plaza accident in April 2013. These increasing pressures from multiple actors (government, MNCs, international, and domestic organisations, etc.) have also brought about new operative challenges for Bangladeshi garment manufacturers. Combined, these developments form an ideal setting in which to seek answers to our research questions.
Rana Plaza collapse aftermath

623 
AAAJ

29,4

\subsection{The context}

The garments industry in Bangladesh is the creation of the World Trade Organisation's Multi Fibre Agreement (MFA) that was in force from 1974 to 2004. Bangladesh had no quota restriction until 1986, a fact that attracted a number of entrepreneurs from quota-restricted countries (mainly South Korea) to undertake joint ventures or subcontracting relationships with Bangladeshi garment manufacturing firms (Labowitz and Baumann-Pauly, 2014). During this period, numerous initiatives were launched by the Bangladeshi government to attract foreign investors and buyers into the sector. Examples include the establishment of Export Processing Zones, a tenyear tax holiday for foreign investors, duty-free importing of machinery and raw materials, and bonded warehouses and back-to-back letters of credit facilities offered to 100 per cent-export-oriented garment companies (McKinsey, 2011). The MFA agreement, combined with the government initiatives, contributed to the rapid growth of the industry, with the number of garment factories increasing from 50 in the early 1980s to 4,200 by 2004 (Kabeer and Mahmud, 2004). In contrast to the predictions of numerous researchers, the Bangladeshi garment sector has observed a 5 per cent increase in growth even since the phasing out of the MFA quota in 2005 (BGMEA, 2014). This surge in growth has resulted from Bangladeshi garment manufacturers' continued, and even greater, focus on lean manufacturing and attention to low-cost, low-valueadded, and large-volume supplies with shorter lead times. These goals have been achieved at the cost of rampant labour exploitation and a rise in unauthorised subcontracting to small factories where working conditions are even worse. Thus, after 2005 , the industry entered a new phase of problems related to poor working conditions and trade union activism (McKinsey, 2011).

On the 24 April 2013, the collapse of Rana Plaza as a result of non-compliance with building safety regulations cost nearly 1,100 workers their lives (Labour Behind Label, 2013). This deadly accident came in the aftermath of the Tazreen Factory fire that had killed 120 workers only five months earlier. These highly criticised incidents influenced western buyers to cooperatively pressurise their Bangladeshi suppliers regarding social compliance (Financial Times, 2013). In May 2013, international labour organisations, non-governmental organisations, and retailers collectively formed the Accord. The Accord is a five-year legally binding agreement to maintain minimum fire and building safety standards in the Bangladesh textile industry. So far, over 150 corporations from 20 countries in Europe, North America, and Australia, two global trade unions, and numerous Bangladeshi unions have signed this legal agreement. As of November 2015, Accord had conducted independent safety inspections at 1,677 factories and issued corrective action plans mainly in the areas of fire, electrical, and structural safety. In factories where safety issues are detected, the Accord ensures that recommendations are carried out by the garment firms, and in severe cases of violation, firms may even be instructed to shut down (Accord, 2015). The suppliers of Accord signatories encompass 1,800 of the total of 6,000 factories in Bangladesh. Thus, with the majority of the factories, and possibly the most vulnerable ones, being outside the scope of Accord inspections, the effectiveness of this initiative has been questioned by Labowitz and Baumann-Pauly (2014).

The BSCI, an initiative of the Foreign Trade Association, is another independent institution that works in parallel with the Accord, covering 40 per cent of Accord-listed suppliers (BSCI, 2014). While the Accord audit mainly focuses on structural dimensions based on its own code on building and fire safety (Accord, 2015), BSCI audits refer to the National Labour Act 2006, covering broader areas of working conditions, wages, 
and human rights (BSCI, 2014). The effectiveness of BSCI audits has also come into doubt after they failed to identify the illegal construction of Rana Plaza during the audits of New Waves Style and Phantom Apparels, the two factories occupying the building, both of which were active suppliers of BSCI brands at the time of the collapse (Clean Clothes Campaign, 2013).

Since the Rana Plaza accident, the government of Bangladesh has also undertaken a number of initiatives under pressure from Western buyers and international development agencies (bdnews24.com, 2013), including an 80 per cent rise in the national minimum wage, and amendments to the National Labour Law stipulating that factories must allow workers to join trade unions without informing their employer, must form workers' participatory committees, must have a central fund to improve living standards, and must provide workers with medical and childcare facilities (Research Initiative for Social Equity Society, 2014). Nevertheless, the implementation of these laws is still weak and the government lacks the resources, the administrative capacity, and often the political will to protect workers' rights. Due to the weak state regulatory system, multinational buyers often require their suppliers to undergo audits by private auditing bodies that they recommend, such as the BSCI and the Accord. As a result, buyers play a significant role in regulating the garment sector in place of the government of Bangladesh (Labowitz and Baumann-Pauly, 2014).

\subsection{Research design}

We have conducted a multiple case study analysis of three small Bangladeshi garment manufacturing firms. The selection of these three firms was based on a number of specific characteristics present within them. First, they undergo audits by the BSCI and the Accord, although they are not actively involved in social reporting. Second, their relationship with the MNE buyers falls in between the two main forms of relationships discussed by Labowitz and Baumann-Pauly (2014). This specific relational context, which Hoque et al. (2016) call "tacit promissory contracting", offers a unique perspective from which to investigate the consequences of compliance and auditing pressures. Third, being small suppliers, these firms are resource constrained, which enables us to examine the strategies they use to simultaneously comply with auditing requirements and survive in this changing environment.

We conducted nine in-depth semi-structured face-to-face interviews, including as interviewees the owners of the firms and two workers for each selected case. The interviews with the owners lasted for 60-90 minutes, while those with the workers lasted for 30 minutes. We also collected organisational documents such as company profiles and histories, production and performance data, the Accord audit reports, and sample design brochures. The firms' owners were contacted through the personal connections of one of the authors, a Bangladeshi national.

All three firms are new-generation factories, established after the MFA era, in 2008-2010 (Table I). These factories have 500-600 employees and five to six production lines. They can be categorised as small-/medium-sized firms that mainly produce tops such as t-shirts and polo shirts and serve European buyers. All three factories have undergone auditing by the Accord and BSCI following pressure from buyers and have received corrective action plans from both auditing bodies.

In their local production networks, these firms hold the position of lead contractor, receiving orders directly from buyers and then sourcing raw materials from their own networks of suppliers in Bangladesh. All three firms have been producing and
Rana Plaza collapse aftermath

625 
AAAJ
29,4

626

\begin{tabular}{|c|c|c|c|}
\hline Dimensions & Firm A & Firm B & Firm C \\
\hline Year of start & 2010 & 2009 & 2010 \\
\hline Country location & Bangladesh & Bangladesh & Bangladesh \\
\hline Number of employees & 500 & 600 & 550 \\
\hline No. of production lines & 5 lines & 6 lines & 5 lines \\
\hline Size & Small & Small & Small \\
\hline Product type & $\begin{array}{l}\text { Tops: graphic } \\
\text { t-shirts, sweatshirts, } \\
\text { hooded jackets }\end{array}$ & $\begin{array}{l}\text { Tops: t-shirt, polo } \\
\text { shirts, jackets }\end{array}$ & $\begin{array}{l}\text { Tops and bottoms: } \\
\text { t-shirts; polo shirts; } \\
\text { shorts }\end{array}$ \\
\hline Service type & $\begin{array}{l}\text { OEM service having } \\
\text { own network of } \\
\text { Bangladeshi } \\
\text { suppliers }\end{array}$ & $\begin{array}{l}\text { OEM service having } \\
\text { own network of } \\
\text { Bangladeshi } \\
\text { suppliers }\end{array}$ & $\begin{array}{l}\text { OEM service having } \\
\text { own network of } \\
\text { Bangladeshi } \\
\text { suppliers }\end{array}$ \\
\hline CSR auditing agencies & $\begin{array}{l}\text { Directorate of labour; } \\
\text { BSCI; Accord }\end{array}$ & $\begin{array}{l}\text { Directorate of labour; } \\
\text { BSCI; Accord }\end{array}$ & $\begin{array}{l}\text { Directorate of labour; } \\
\text { BSCI; Accord }\end{array}$ \\
\hline Origin of buyers & $\begin{array}{l}\text { Mainly the } \\
\text { Netherlands; other } \\
\text { European countries }\end{array}$ & $\begin{array}{l}\text { The Netherlands, } \\
\text { Belgium, and Spain }\end{array}$ & The UK and Italy \\
\hline $\begin{array}{l}\text { Means of contact with } \\
\text { buyer }\end{array}$ & Direct & $\begin{array}{l}\text { Direct and buying } \\
\text { house }\end{array}$ & $\begin{array}{l}\text { Direct and buying } \\
\text { house }\end{array}$ \\
\hline $\begin{array}{l}\text { Length of } \\
\text { relationships with } \\
\text { buyers }\end{array}$ & $\begin{array}{l}\text { Mixed (long term } \\
\text { and short term) }\end{array}$ & $\begin{array}{l}\text { Mixed (long term } \\
\text { and short term) }\end{array}$ & $\begin{array}{l}\text { Mixed (long term } \\
\text { and short term) }\end{array}$ \\
\hline Ownership structure & $\begin{array}{l}\text { Investment from } \\
\text { Turkish and } \\
\text { Bangladeshi owners } \\
\text { (joint venture) }\end{array}$ & $\begin{array}{l}\text { Owned by two } \\
\text { brothers (local) }\end{array}$ & $\begin{array}{l}\text { Owned by two } \\
\text { friends (local) }\end{array}$ \\
\hline $\begin{array}{l}\text { Accord compliance } \\
\text { level } \\
\text { BSCI compliance }\end{array}$ & Yellow & Yellow & Yellow \\
\hline level & $89 \%$ & $91 \%$ & $75 \%$ \\
\hline Defect rate & $7 \%$ & $8 \%$ & $8 \%$ \\
\hline $\begin{array}{l}\text { Labour turnover } \\
\text { rate }\end{array}$ & $7 \%$ & $8 \%$ & $9 \%$ \\
\hline $\begin{array}{l}\text { Surrounding } \\
\text { environment }\end{array}$ & $\begin{array}{l}\text { Urban area; rented } \\
\text { building }\end{array}$ & $\begin{array}{l}\text { Industrial area; own } \\
\text { building in industrial } \\
\text { area }\end{array}$ & $\begin{array}{l}\text { Industrial area; } \\
\text { rented shared } \\
\text { building }\end{array}$ \\
\hline \multicolumn{4}{|l|}{ Workforce nationality } \\
\hline Managers & $\begin{array}{l}\text { Bangladeshi and } \\
\text { foreigner }\end{array}$ & Bangladeshi & Bangladeshi \\
\hline Supervisors & Bangladeshi & Bangladeshi & Bangladeshi \\
\hline Workers & Bangladeshi & Bangladeshi & Bangladeshi \\
\hline
\end{tabular}

supplying finished apparel for the same buyers since the time of their inception, although there was no legally binding original agreement for repeat purchases. As a result, each transaction has been carried out as a discrete repeat transaction that is almost never confirmed. Instead, there is an implicit (or at most orally expressed) promise of future orders that is subject to their ability to maintain the expected level of performance within the current exchange in terms of price and quality specifications, on-time delivery, social compliance, and protection of intellectual property. In contrast to what is conceptualised as direct sourcing in the NYU Stern report (Labowitz and 
Baumann-Pauly, 2014), these firms have not received long-term order forecasting, and have neither the security to invest in economic upgrading nor business incentives for high performance or compliance. Nevertheless, they have had to make a moderate degree of relationship-specific investment, such as the purchase of customised raw materials, the specialisation of the labour force, and that resulting from the corrective action plans from the Accord and BSCI audits, in order to be able to meet the individual buyers' expectations. This investment has been necessary not only for the completion of their current transactions but also to ensure that the buyers' implicit promises to make repeat purchases are realised. This relationship is expressed as "tacit promissory contracting" in Hoque et al. (2016), where it is defined as "a form of outsourcing relationship whereby supplier firms [have been] involved in recurrent discrete transactions with the same buyers since their inception, but without the existence of any original legally binding written agreement". All three factories, therefore, share the above similarities in terms of size, auditing, and accountability requirements, and type of relationship with their MNE buyers.

The factories also have some minor differences in terms of surrounding area, ownership structure, workforce nationality, and rental arrangements. Some other minor yet important differences are their Accord and BSCI inspection levels, defect rates, and productivity rates. We analysed the data using template analysis (King, 2014). Table II shows the initiatives undertaken by all three firms to comply with the corrective action plans of the BSCI and Accord audits, and the intended and unintended consequences of these initiatives. Table III summarises the implications of these initiatives for the firms and their workers in terms of economic upgrading, social upgrading, and social value creation. The dimensions used for analysing the implications for economic upgrading (capital and labour) and social upgrading (measurable standards and enabling rights) were adapted from Barrientos et al. (2011). The definition of social value creation proposed by Sinkovics et al. (2015) was used to evaluate the extent to which the initiatives undertaken for social upgrading purposes also create social value for the workers, that is, how much they enable or infringe their social, economic, and cultural rights.

\section{Results}

The analysis yielded two key findings. First, external pressures on the firms to implement the measurable/tangible dimensions of the BSCI and the Accord achieved their intended purpose, that is, the creation of a safer, better equipped, and more comfortable working environment. Nevertheless, there have been a number of unintended consequences. Due to the high cost of compliance, the case companies were forced to terminate initiatives that had catered to some of the socially grounded needs and priorities of workers. A closer investigation of these initiatives through the lens of social value creation (Sinkovics et al., 2015) led to the following observation: while certain compliance initiatives can be classified as social upgrading and thus fulfil their intended purpose, they may at the same time destroy existing social value and lead to the impairment of certain social, economic, and cultural rights.

Second, in order to cover the sizable cost of compliance and to ensure the survival of their companies, the owners have invested in technological upgrading. At the same time, they have increased the pressure on the workforce to further enhance the efficiency of production. Despite this economic upgrading, there has been no improvement in workers' skills. Rather, it has resulted in an increase in the power imbalance and the exclusion of unskilled workers from the job market. The changes
Rana Plaza collapse aftermath 

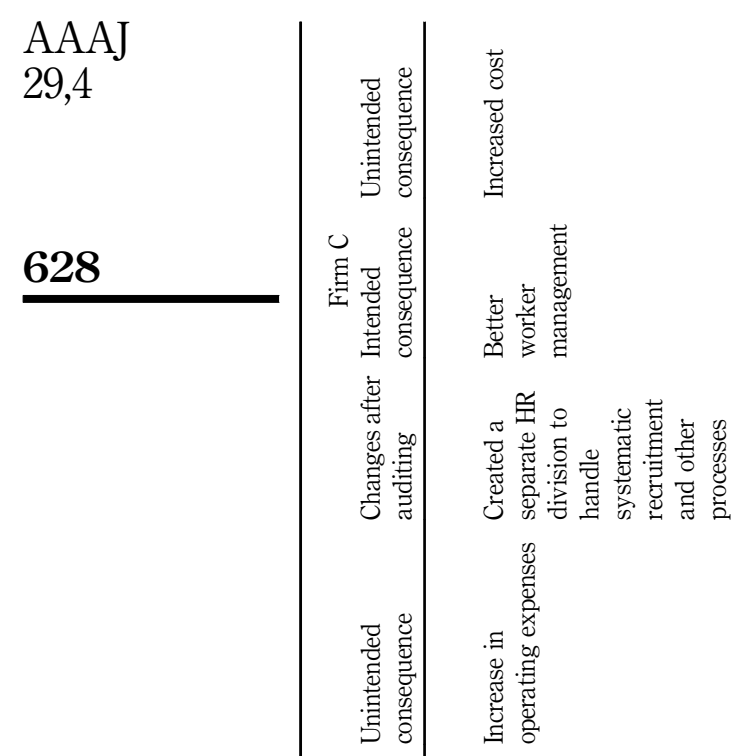

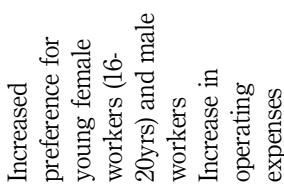

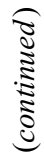

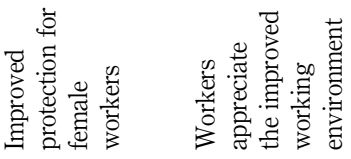

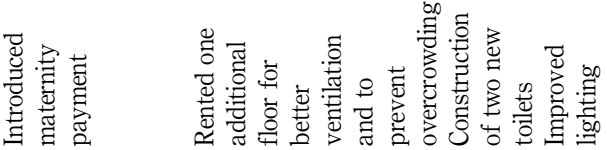

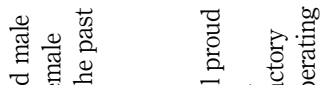

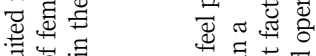

窇㟔

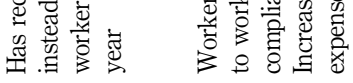

吉总

究密

马.

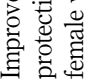

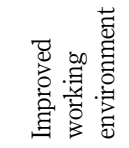

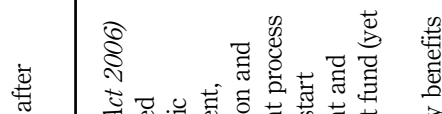

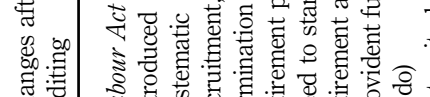

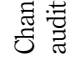

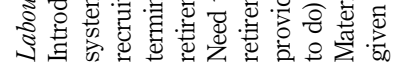

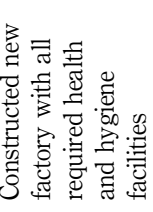

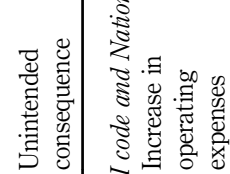

ฐัฐ

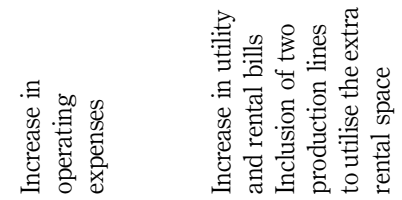

Table II.

BSCI and Accord compliance:

initiatives and

consequences
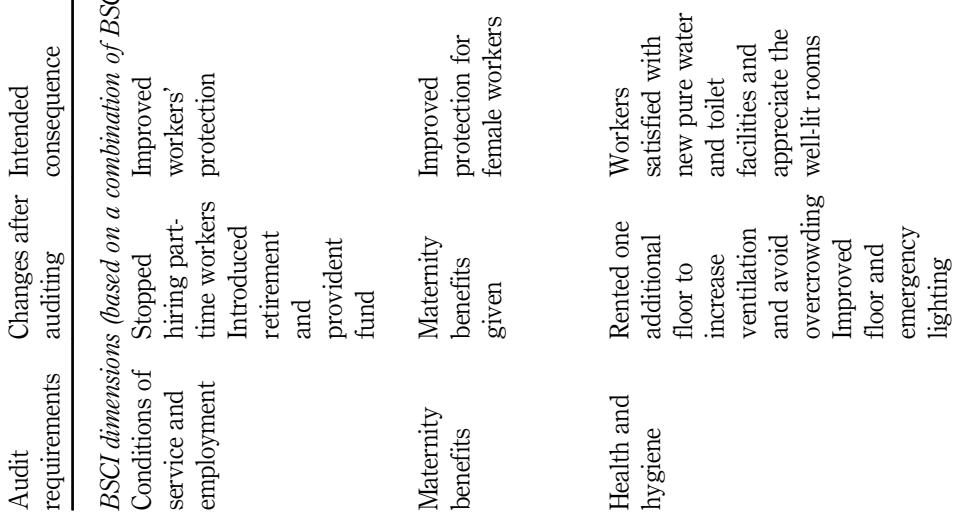


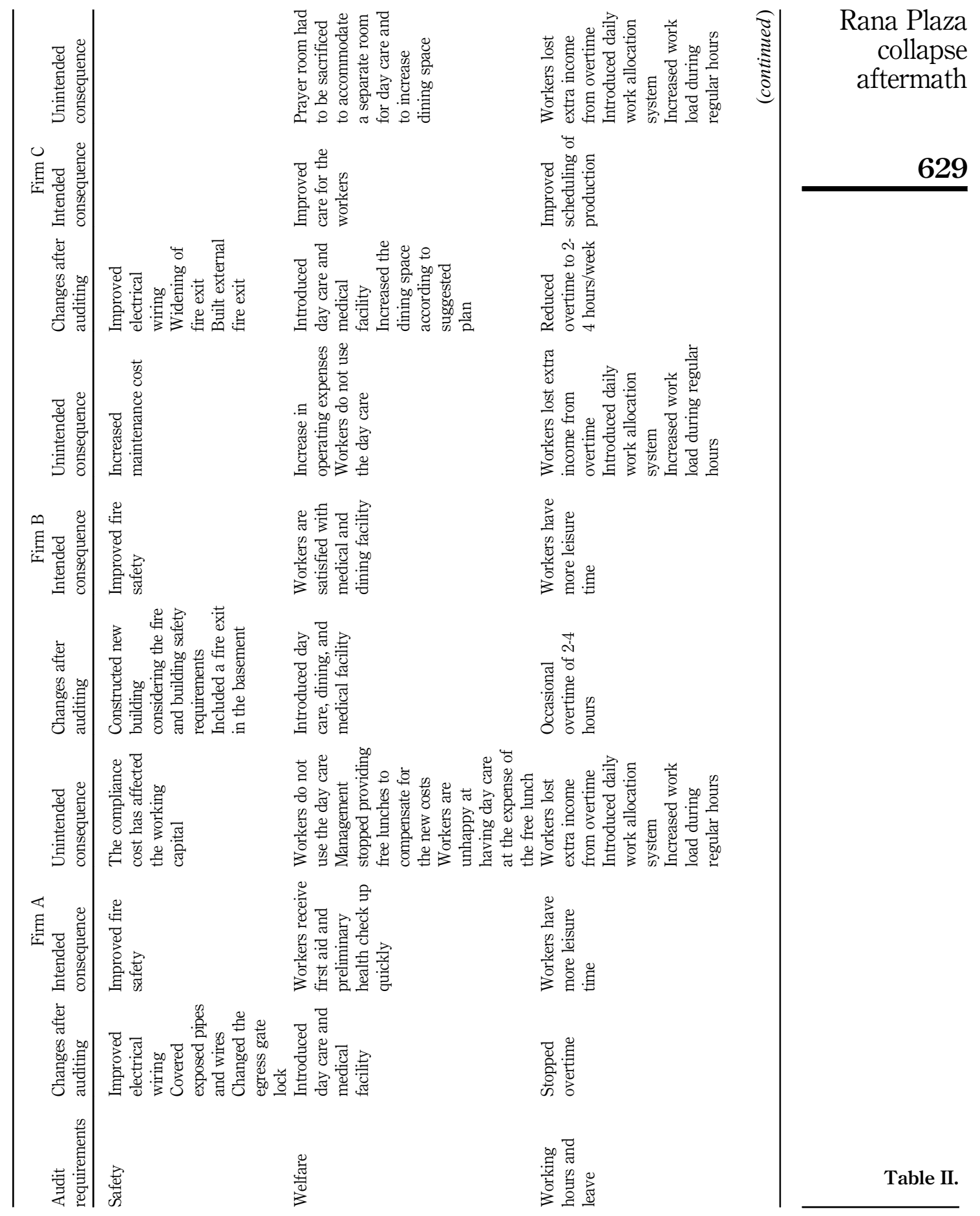


AAAJ
29,4

630

\begin{tabular}{|c|c|c|c|}
\hline 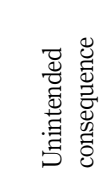 & 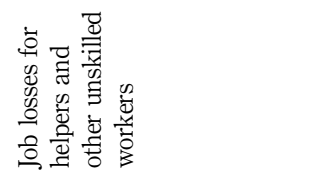 & 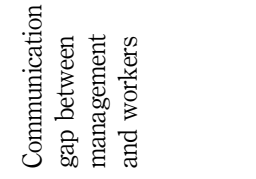 & 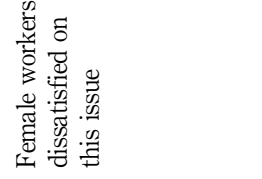 \\
\hline 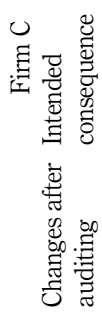 & 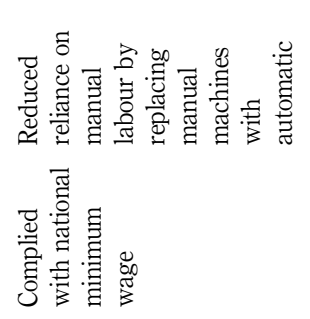 & 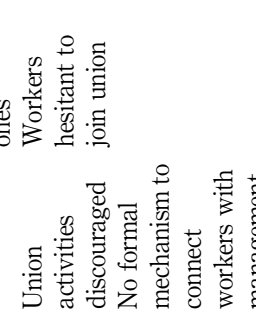 & 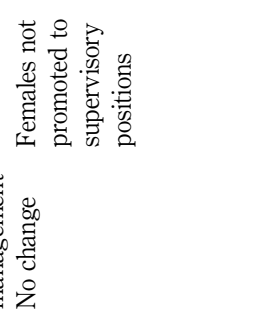 \\
\hline 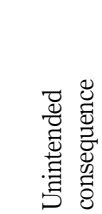 & 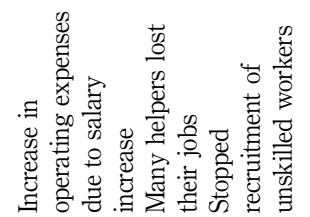 & 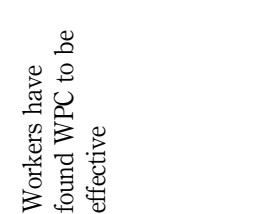 & 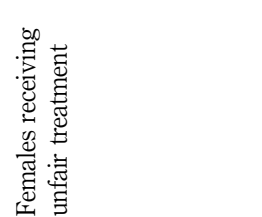 \\
\hline 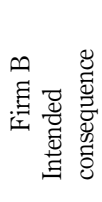 & 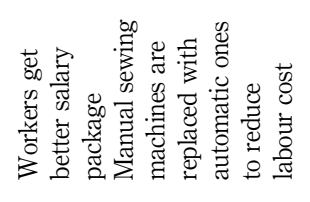 & 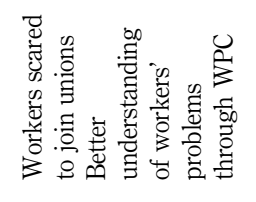 & 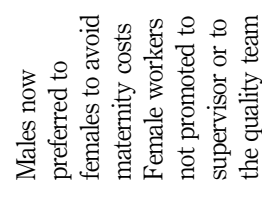 \\
\hline 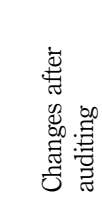 & 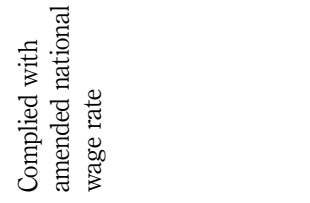 & 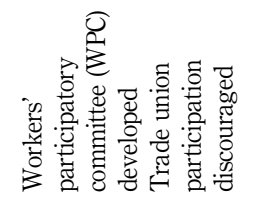 & 更 \\
\hline 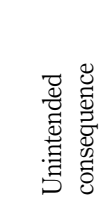 & 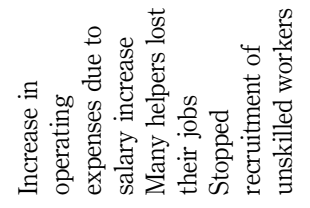 & 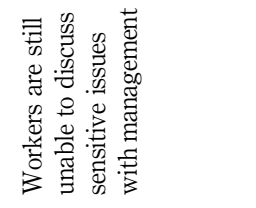 & 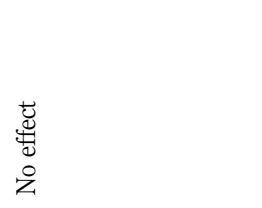 \\
\hline 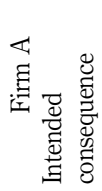 & 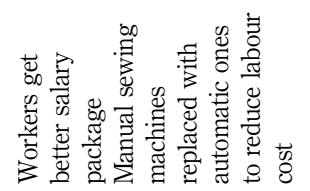 & 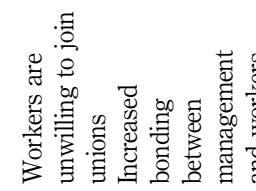 & 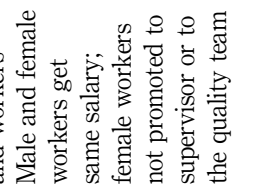 \\
\hline 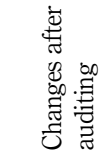 & 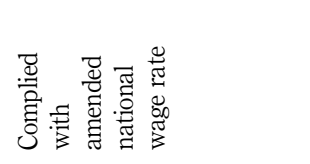 & 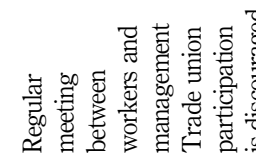 & 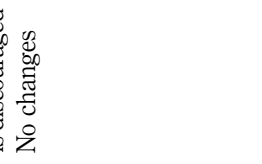 \\
\hline 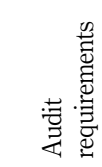 & 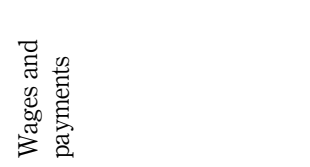 & 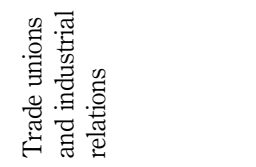 & 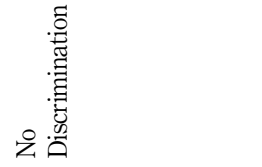 \\
\hline
\end{tabular}

Table II. 


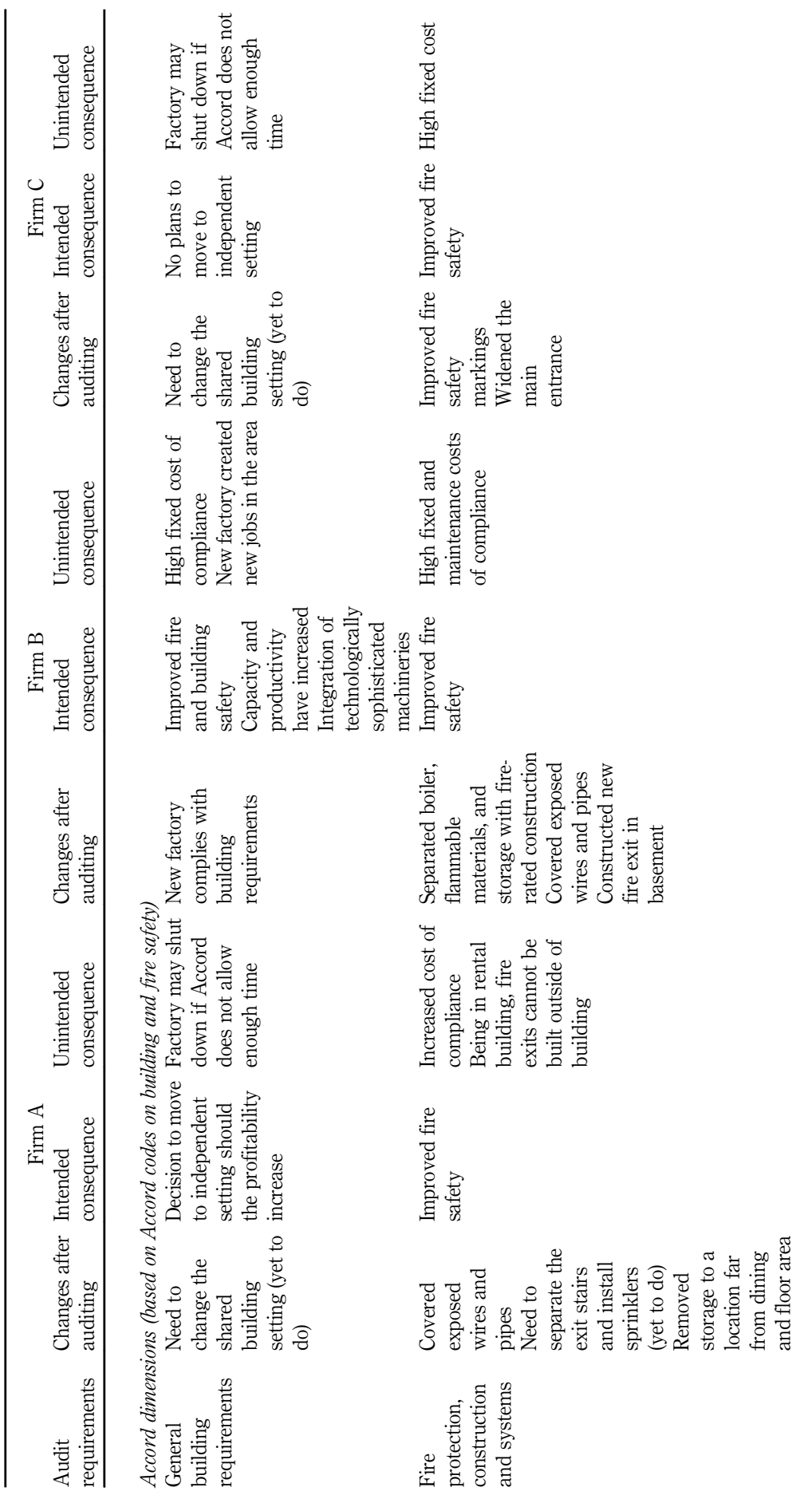

Rana Plaza

collapse aftermath

631

Table II. 


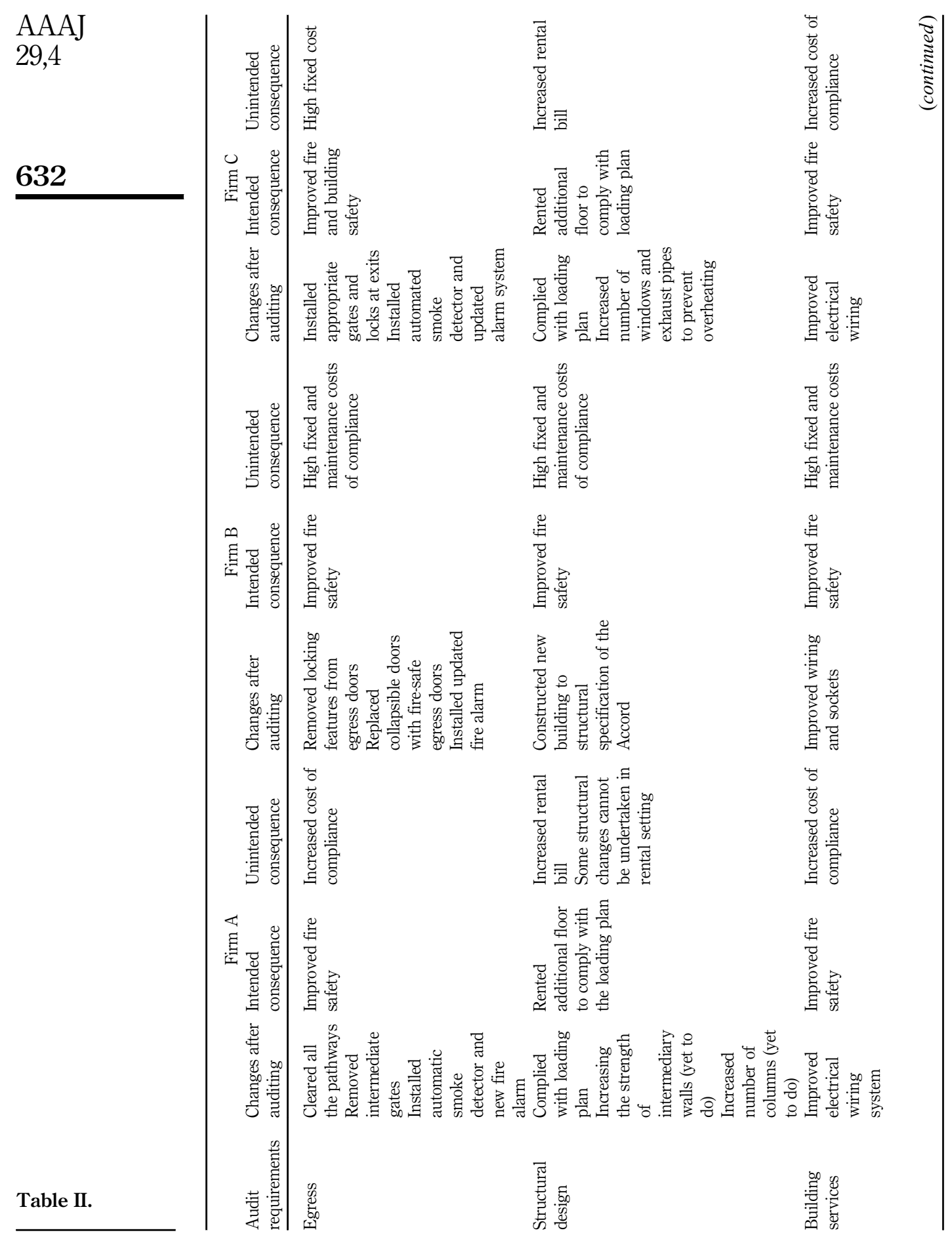




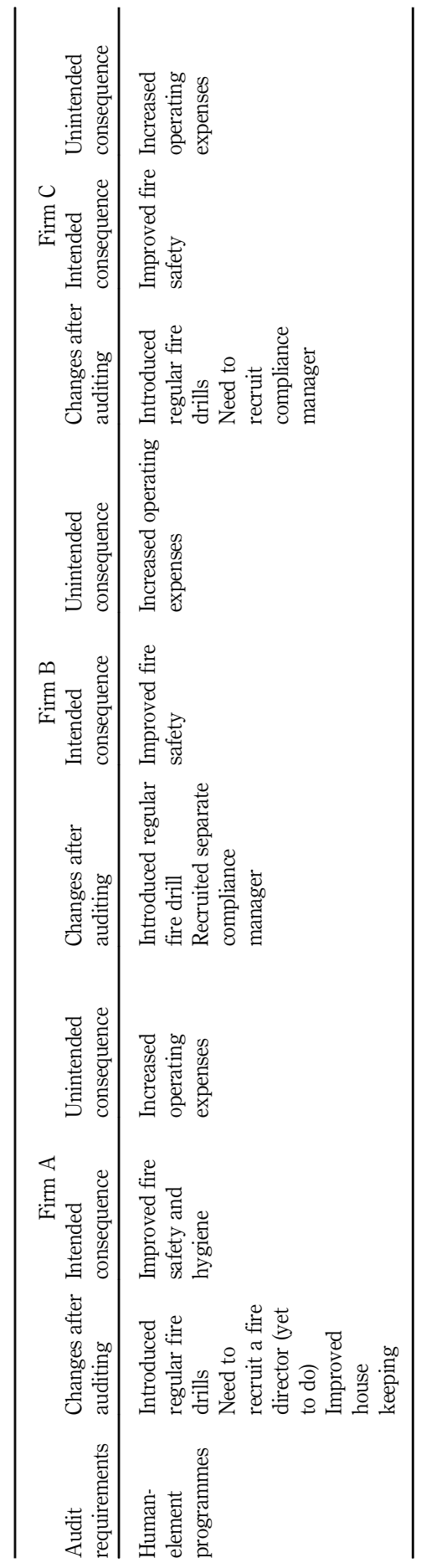

Rana Plaza collapse aftermath

633

Table II. 


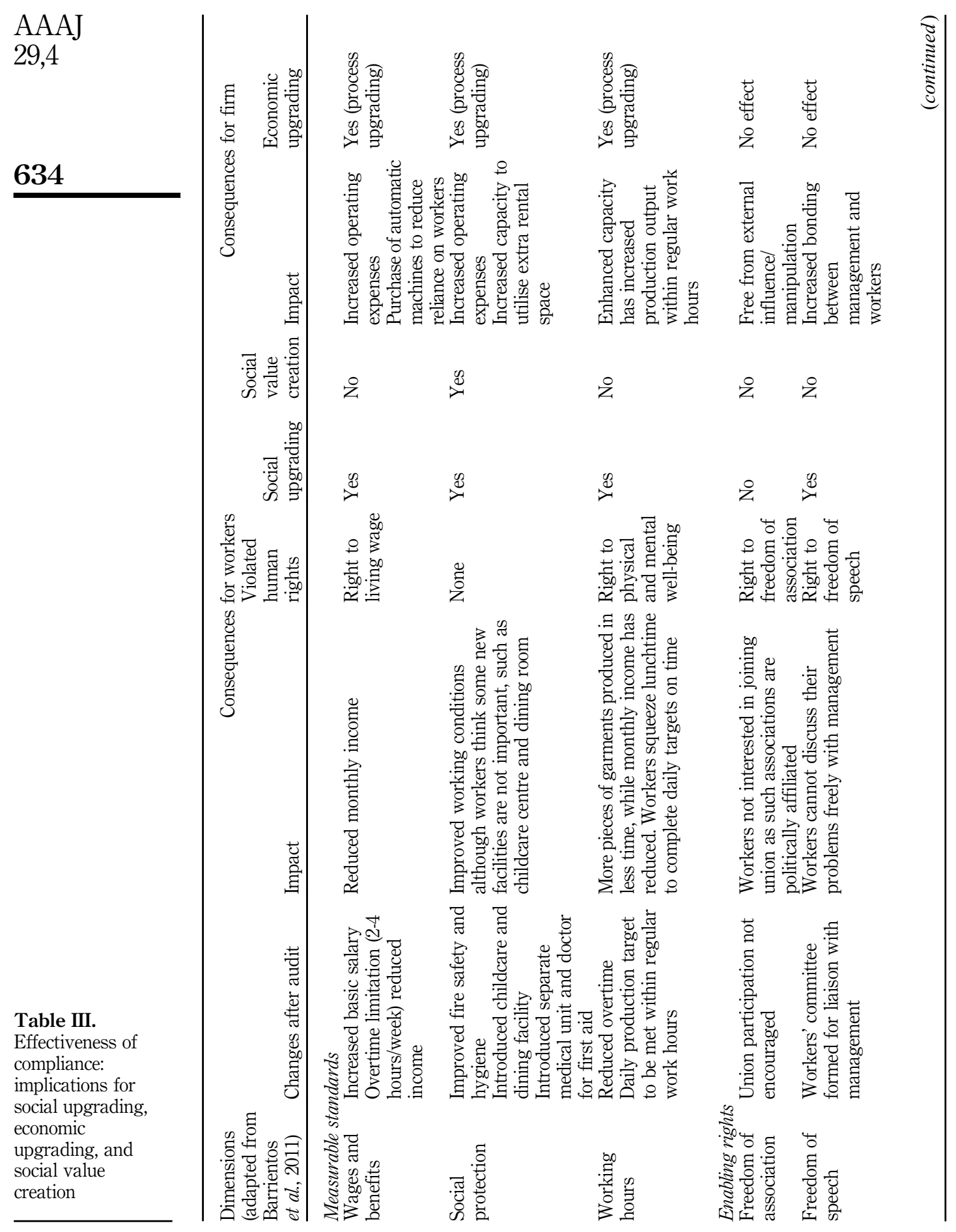




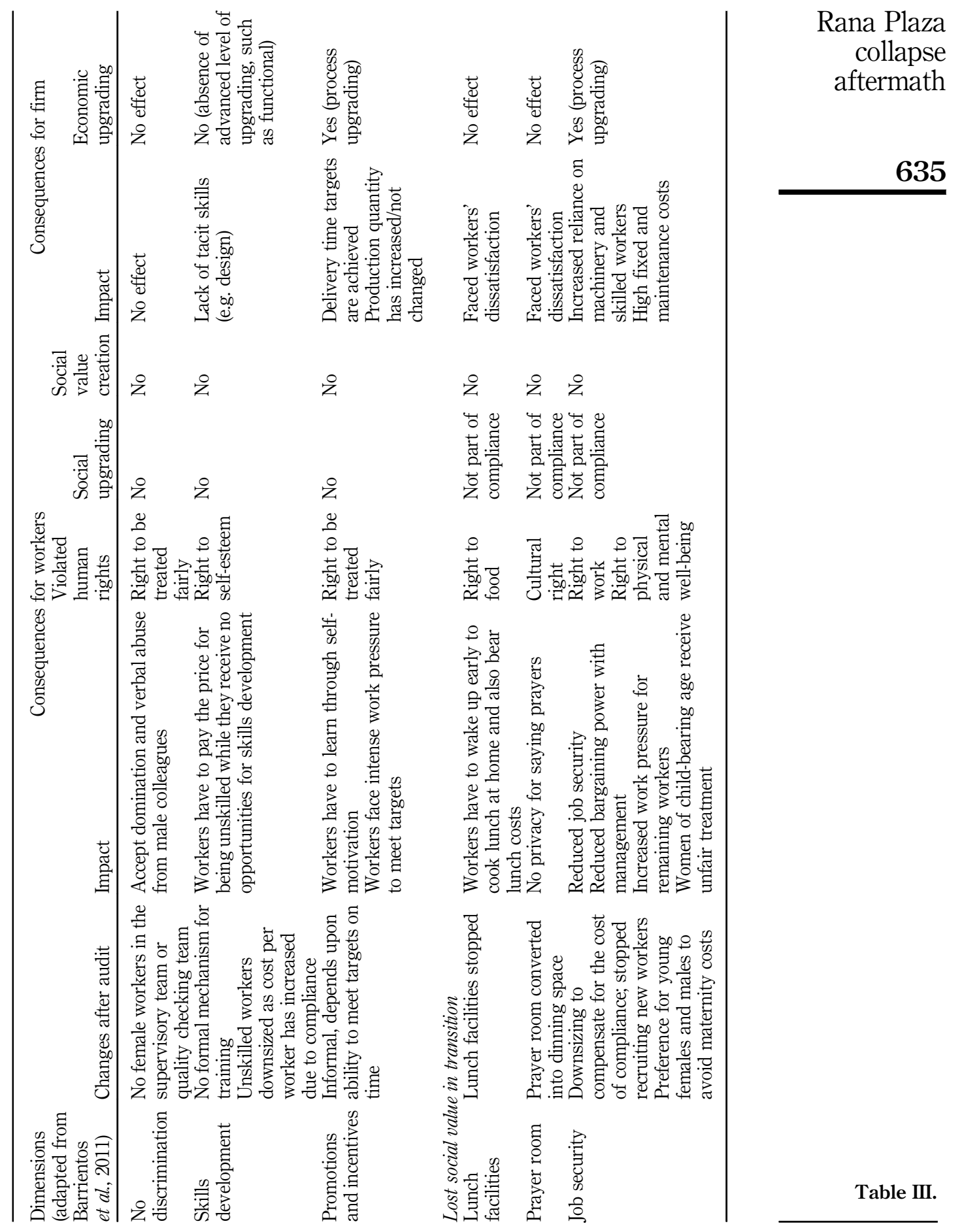


AAAJ 29,4

636

undertaken by the case firms to achieve compliance, and the implications of these changes, are summarised in Tables II and III. The rest of this section will describe the cases in detail.

\subsection{Firm $A$}

Background. Firm A has an international owner structure. In 2010, two friends from Bangladesh and the Netherlands decided to set up a garment exporting business and established a buying house in Bangladesh. They created a liaison office in the Netherlands responsible for identifying buyers and receiving orders. The orders, once received, were outsourced to small local contractors by the Bangladeshi buying house. The buying house could source only low-value-added garments that Bangladeshi factories can typically manufacture. After a year, the partners convinced a Turkish entrepreneur to join them. The idea was to establish a joint venture factory in Bangladesh to produce more sophisticated products. The Turkish partner already had a factory in Uzbekistan and wanted to exploit the opportunity of cheap labour in Bangladesh. Thus, the Bangladeshi factory was created in 2011. It mainly targets European buyers, mostly based in the Netherlands. While the company also has a few irregular, short-term buyers, most of their buyers are regular and long term. They contact these buyers directly via their office in the Netherlands. They produce graphic t-shirts, hooded jackets, etc.

Changes undertaken to achieve BSCI and Accord compliance: implications for social upgrading. The factory underwent its first Department of Labour (a state organisation) inspection in 2011 and passed it. Following pressure from buyers, the factory joined the BSCI in 2012. It achieved 91 per cent compliance in the most recent BSCI audit in early 2014. As most of its long-term buyers had joined the Accord, the business underwent an Accord inspection in late 2013 and achieved "yellow level". Since the factory joined the BSCI in 2012, it has started implementing improvements such as fire exits, fire markings, and the installation of exhaust pipes. As a result, it achieved 89 per cent compliance in its first BSCI audit. Nevertheless, following its first inspection, the BSCI recommended the provision of day care, medical, and proper dining facilities, increased ventilation, more space in the work areas, and a change of storage location. The owner of Firm A stated that, in order to implement these recommendations, they had rented an additional floor so that they could accommodate a day care centre, a dining hall, and a medical room. They had also reduced their limit on working overtime to a legally approved two hours per day. With all these changes made during 2013-2014, their BSCI compliance improved from 89 to 91 per cent and the attrition rate fell from 8 to 7 per cent, which is lower than the industry average. The owner further informed us that, until January 2014, they had provided a free nutritious lunch to workers. However, they had had to stop providing this service in order to cover the cost of the mandatory compliance requirements. In the owner's own words:

I introduced the free lunch in 2010 because I knew that workers often cannot eat proper nutritious food at home. I want to keep them healthy. It is also beneficial for me, because if they are healthy then they can work more efficiently. If they can rest one hour more at home instead of cooking lunch, then they can come to work on time and with a fresh mind [...] but I could not manage the cost and I had to allocate resources based on priority.

This comment indicates that the lunch provision service was stopped not because of the management's lack of care for their workers, but because they had to prioritise 
complying with the Accord codes over workers' needs. The owner furthermore indicated that some of the Accord recommendations would have been difficult to implement as they would have required structural changes to the building. Examples include increasing the number of windows and installing sprinklers. What adds to the complexity is that the building is rented and shared with other factories and a few shops. This was indeed picked up by the Accord auditors. However, the construction of a new building would require massive investment and time. A move to an independent rented building would also involve high switching costs since commercial buildings are often more than six storeys high and require very high rental deposits. Furthermore, there would be a lot of unused space. For this reason, Firm A has not been able to comply with all of the Accord's recommendations. The owner indicated that the firm may need to shut down entirely, should the auditors insist on these changes.

The analysis of this case further revealed that, although the factory has achieved a high degree of compliance, a number of workers' rights are still being violated, such as freedom of association, gender equality, and career/skills development. The owner made the following comment in this respect:

Now buyers are pressurising us to let our workers join trade unions. But we don't want this to happen. We discourage our workers from joining trade unions. We want to prevent union leaders from getting easy access to the factory via our workers and interfering in factory operations by misusing their political links. To be honest, our workers also realise that unions are no good; unions talk less in workers' favour, and more for their own political interest.

The interview data show that female workers are mostly given opportunities as operators and helpers (90 per cent occupied by females) and are not promoted to supervisory level (100 per cent occupied by male). Workers indicated that they did not receive any sort of formal job description or training, although their promotion depended on learning new skills. As a result, they said, they mainly acquired skills on their own initiative, from senior colleagues. Therefore, it seems that issues such as gender imbalances and skills development represent neglected areas.

Implications of BSCI and accord compliance for economic upgrading. The management had undertaken two strategies to compensate for the cost of complying with the corrective action plans of the BSCI and the Accord. First, they had decided to find ways to increase their profit margin; second, they had tried to increase production efficiency to reduce costs. In 2013-2014, investment in computer-aided machines and sophisticated graphics and appliqué machines had allowed the firm to produce higher value-added fashionable garments and earn a higher profit margin. During this period, two more production lines were introduced to make optimal use of the spare space, rented primarily to accommodate the BSCI and Accord recommendations. Further to this, to compensate for the increased per-unit labour cost, 80 per cent of the manual machines were replaced with automatic sewing and thread-trimming machines, resulting in reduced reliance on helpers. The increased capacity along with the replacement of manual machines had resulted in a 5 per cent increase in the productivity rate and a 2 per cent reduction in the defect rate.

The impact of initiatives on workers: implications for social value creation. The interviews with the workers of Firm A reveal that, since 2014, their basic salary has increased due to the recent rise in the national minimum wage. Their daily working hours have also been reduced due to the new national overtime hours ceiling. As a consequence, management has been less willing to allocate overtime as the hourly rate
Rana Plaza collapse aftermath

637 
AAAJ

29,4

for it has increased significantly. This has resulted in a situation whereby, although workers can spend more time with their families, their cumulative monthly incomes have declined due to the decreased amount of overtime hours. In the words of a machine operator we interviewed:

Until recently my monthly take away income after 10-14 hours/week of overtime was TK10,450, whereas with the new wage rate and overtime limit my monthly income came down to TK8,500. This change in income has affected our living standard, creating difficulties in paying house rent and school fees for our children.

A further implication has been the increase in pressure during regular working hours. As a result of the new overtime limits, workers are given a set daily target that often proves over-ambitious and impossible to achieve within regular working hours. In order to meet the target, workers end up staying longer without being paid overtime.

Workers also reported a decrease in job security. The purchase of new machines to improve the quality of garments and to make the production process more efficient has meant that some less qualified workers have lost their jobs. At the time of the interviews, 15 helpers had lost their jobs due to the acquisition of the machines. Increasing compliance pressures have also meant that most factories have stopped recruiting unskilled workers (e.g. helpers and operators), thus excluding them from the job market. As a consequence of their reduced job security, their bargaining power vis-à-vis their employers has also decreased. Workers furthermore complained about the loss of free nutritious lunches. The loss of the canteen has meant less time for rest and more money spent on food. The free lunch had in fact been one of the key factors that had attracted many workers to this particular factory.

\subsection{Firm $B$}

Background. Established in 2009 and owned by two brothers, Firm B started its journey with a two-line factory in a rented shared building in Dhaka city. During early 2013, they constructed a new factory unit in Gazipur industrial zone, starting production there in late 2013. The new factory has 600 employees and six production lines. The new building was constructed in line with the BSCI and Accord building safety guidelines. The new factory mainly produces tops such as t-shirts, polo shirts, and jackets. Their main buyers are from the Netherlands, Belgium, and Spain. Some of their most important long-term buyers are Bristol, Intersport, and Lonsdale. They also arbitrarily search for new buyers to use up their remaining capacity.

Changes undertaken to achieve BSCI and Accord compliance: implications for social upgrading. Firm B started out in a rented shared building. In late 2012, they decided to move to their own establishment. The main reason for this was the increased pressure to achieve BSCI compliance after the Tazreen Factory fire in 2012. Furthermore, the management realised that the rental arrangement and severe space limitations would prevent them from complying with most of the BSCI audit recommendations, such as providing day care, dining, and medical facilities, more space, etc. The new factory achieved 91 per cent compliance in its first BSCI audit in late 2013. In early 2014, it received "yellow level" from the Accord. The Accord recommendations included the installation of an additional fire exit in the basement, changing the locks at egress gates, upgrading the fire alarm system, and covering exposed wires and pipes.

At the beginning of 2014, they began to increase workers' salaries and reduce their official working hours to comply with national regulations. Similarly to 
Firms A and B works with daily set targets that workers are expected to achieve within regular work hours. The motivation for avoiding overtime was mainly due to the increased overtime payment rates imposed by the government. The new factory was built with a childcare centre, medical facilities, and suitable dining facilities following the recommendations from an Accord inspection.

In contrast, unionisation of workers is actively discouraged and the issue of gender discrimination has not been addressed, with 80 per cent of workers female and all supervisory positions occupied by men. One of the owners expressed the following opinion regarding unionisation:

We strongly discourage our workers from joining unions; we rather encourage them to bring their problems to us directly, be those personal or work-related. With most problems being tied to firm policies and activities, we believe that we can understand and are equipped to address the problem better than someone [union authority] who is external to the problem situation.

Implications of BSCI and Accord compliance for economic upgrading. The construction of the new production unit was primarily driven by the need to comply with BSCI audit recommendations, which would have been impossible to implement in Firm B's previous small rental setting. While the old factory has continued as a CMT service provider, the new one has achieved OEM status by sourcing raw materials from its own network of local suppliers (95 per cent) and providing a full-package service to the buyers. The higher profit margin achieved through the provision of OEM services has proved to be critical in compensating for the costs of compliance. In the words of one of the owners:

It was not feasible to continue as a CMT supplier in our new setting, because the profit margins would have been too low to cover the cost of maintaining a fully compliant factory. Therefore, we had to offer more value to our customers by providing them with a full-package service instead of just cut, make and trim. Nevertheless, the absence of financial capacity constrained us from establishing in-house backward linkage units, and as an alternative we rely on a network of external suppliers for the supply of raw materials.

The above comment shows that, although BSCI compliance was the key driver of the establishment of the new factory, the long-term survival of the firm and profitability issues were also considered when it was set up. As a consequence, the factory was equipped entirely with automatic machines to ensure increased productivity and reduced reliance on helpers, computer-automated design machines for enhanced design accuracy, and CCTV cameras on the factory floor to detect theft as well as any abuse of workers or negligence. The owner reported that there had been a reduction in defect rates from the previous 12 to 8 per cent, and an increase in workers' productivity from 28 to 35 per cent during 2013-2014. As one of the owners put it:

We had to survive in business at the same time as being compliant and, in so doing, we had to find ways to compensate for the increased operating expense and per-unit labour cost. Thus, while setting up the new factory, we not only considered implementing the BSCI codes but also means to increase sales and profitability. We therefore equipped the factory with technologically sophisticated machinery that would allow us to reduce our reliance on labour and increase productivity in the long term.

The above comment indicates that their pursuit of economic upgrading has been efficiencyoriented. As a significant increase in workers' skills was not required to achieve this goal,
Rana Plaza collapse aftermath 
AAAJ

29,4

640

the factory has not yet taken any initiatives to offer formal training to workers. The new recruits receive on-the-job training from supervisors and further skills development depends on the recruits' own willingness and ability to self-instruct or learn from colleagues.

The impact of initiatives on workers: implications for social value creation. The interviewed workers indicated that working in a compliant factory had increased their social status. One of the interviewed workers, who had recently transferred from the old factory, greatly appreciated the better environment of the new factory. On the other hand, this improvement has affected their bargaining power:

As the owners now have a compliant factory their bargaining power has increased. They can now get skilled workers very easily. As a result, our job security has decreased. They can make us redundant at any minute to recruit someone more skilled.

This has resulted in reduced job security, especially for the unskilled workers. The heavy investment in machinery has also affected workers' job security. Similarly to at Firm A, opportunities for workers' personal and skills development are limited:

On the one hand, management has warned us that if we do not work efficiently, then we will be sacked right away. On the other hand, most of us don't know how we can improve our skills, how we can learn new skills [...] When I joined, one of our senior colleagues showed me the sewing task, i.e. handling the sewing machines, understanding the cut pieces and stitching them together. Until now I have been doing the same task every day [...] In essence, whatever new tasks we learn, we learn them on our own from our senior colleagues.

Workers also reported heightened work pressures and decreased monthly income due to the reduction in overtime payments. Furthermore, there have been complaints about abusive language from supervisors should they fail to meet the daily target. On many occasions they have had to sacrifice their lunch break to catch up with the pending work load. The workers also reported an increase in the number of young male recruits in the past year - a trend that they had only noted since the introduction of maternity benefits.

\subsection{Firm $C$}

Background. Firm C was set up in 2010 in the Gazipur industrial zone, on the top floor of a rented shared building, with three lines. In early 2013, the firm rented another floor in the same building. Currently, it has five production lines and nearly 550 workers. It specialises in producing tops such as basic t-shirts and polo shirts, and during the summer season it occasionally produces casual and beach shorts. Firm C's buyers are Bench from the UK, and Piazza and Cotton SRL from Italy. It has also worked for Pierre Cardin for two summer seasons. While most buyers are contacted directly, the factory has also worked for buyers contacted through buying houses, including Watson from Holland, Bristol from Italy, and E5 and V\&V from Spain.

Changes undertaken to achieve BSCI and Accord compliance: implications for social upgrading. After the Rana Plaza incident, Firm $\mathrm{C}$ experienced pressure, mainly from two buyers, Bench and Bristol, to improve its working conditions. It then became a member of the BSCI in June 2013. In the first BSCI inspection in December 2013, it achieved 67 per cent compliance. In January 2014, it received "yellow level” certification from the Accord. The BSCI auditors recommended the provision of childcare facilities, increasing the space in the dining hall, and introducing a provident fund, maternity benefits, and an on-site medical facility. The Accord's recommended corrective actions included improving the fire safety markings, widening the main gate, improving the 
electrical wiring, and moving to an independent building. Following these recommendations, Firm $\mathrm{C}$ established a medical facility, increased the space in the dining hall, widened the main gate, and improved the fire markings and electrical safety. As a result, its BSCI compliance increased to 75 per cent in 2014. However, similarly to Firm A, it has not been able to implement a large number of the Accord's recommendations that would require structural changes such as building an external staircase, as it does not own the building.

The owner indicated that there were three obstacles to further investment in compliance. The firm lacks financial resources and there is no assurance from buyers that they will increase their orders or pay more for increased compliance. Most importantly, should the pressure to move into an independent building increase, the business may have to close down altogether due to a lack of sufficient capital with which to rent or construct an independent building.

The analysis also revealed that, in order to increase their code compliance, the company had had to sacrifice some services it had previously provided for workers. For example, the dining hall had been enlarged at the cost of the prayer room adjacent to it. With almost 99 per cent of the workers Muslim, the majority would have prioritised the prayer room over a Western-style dining setting. Furthermore, in order to cover the cost of the childcare facilities, the management had had to stop providing free lunches for workers. At the same time, Firm $\mathrm{C}$ was trying to recruit new buyers to increase its revenues. However, while the number of orders was increasing, the business had stopped hiring workers at the helper and operator level:

We know there is a grievance among workers as their work pressure has increased within their routine hours. Moreover, their prayer room has been taken away. Now, they pray in random corners of the factory floor. As a Muslim I feel guilty for doing this [...] Now they have to bring their own lunches. We feel bad about all these changes, but our hands are tied as well. At least they should be happy that our factory is up and running. I know that two of my friends have already closed their factories because they could not keep up with the pressure.

In terms of workers' enabling rights, Firm C displays some similarity with Firms A and B. Freedom of association, gender equality, and career development are issues that are unaddressed so far. The management showed a preference for recruiting male and young female workers (16-20 years) over females of child-bearing age (20-35 years) to avoid the mandatory payment of maternity benefits.

Implications of BSCI and accord compliance for economic upgrading. Firm $\mathrm{C}$ has added two more production lines to make optimal use of the additional space that has primarily been rented to accommodate BSCI audit requirements. This extra capacity has accommodated higher order volumes from existing and new buyers. The owner informed us that they had replaced 50 per cent of the manual machines with automated ones in order to reduce labour costs. As a consequence, the production capacity had increased by 7 per cent. However, the products produced are still low-value-added and the productivity rate is 30 per cent, which is far below the industry average of 40 per cent. The firm offers on-the-job training for the workers in their specialised tasks. There is no systematic training to increase workers' productivity.

The owner of Firm $\mathrm{C}$ expressed his reservations towards investing in economic upgrading and referred to the shared building as the key constraint:

We realise that there is a need for investment in upgrading our services and machinery in order to enhance the profit margin, which in turn could also compensate for the high cost of compliance. 
AAAJ

29,4

642
The Accord inspectors recommended to us that we move to an independent building and indicated that a failure to do so may cause us to fail the next audit. Our current resources do not allow us to rent an entire commercial building or build our own. With this pressure on top of everything else, our future is uncertain, which de-motivates me from investing further in upgrading of any sort.

The impact of initiatives on workers: implications for social value creation. The interviewed workers agreed that there had been a gradual improvement in working conditions over the years. They valued significantly some of the recent changes made by the factory, such as the widening of the main entrance of the building, the increase in the number of fans on the floor area and the provision of masks to prevent the inhalation of textile fumes. In contrast, they were highly critical of the decision to stop providing lunch. The workers commented that the free lunch facility had not only used to cut their costs but had also helped them to arrive at work on time without rushing:

We do not need a childcare facility as none of [us] use that facility. Our mother-in-laws will not let us bring our children to work. However, we need lunch; if we are to cook lunch at home, then we have to wake up at five in the morning. We are too tired to do that after 8-10 hours of factory work followed by domestic work at home.

The workers therefore stated that they would prioritise the lunch facility over the childcare facility, which they hardly used. They also objected to the loss of the prayer room:

We never have dinner on a dining table at home. Thus, a spacious dining place with proper tables and chairs is not important for us, definitely not [when it means] compromising on [having] a separate place for saying prayers. Now we have to say prayers in front of our male colleagues, which is a Gunaah [sin].

Similarly to in the other two cases, workers also reported a reduction in their monthly income and increased work pressures.

\section{Discussion, conclusion, and limitations}

Our study set out to investigate the intended and unintended consequences of compliance and auditing pressures for three Bangladeshi garment manufacturers and their workers. More specifically, the present study can be seen as an attempt to evaluate the impact of new factory safety and capacity-building initiatives that were a response to the Rana Plaza accident, such as the Accord and the BSCI (cf. Labowitz and Baumann-Pauly, 2014). The findings indicate that compliance can have some positive benefits in terms of improved working conditions such as better health and safety measures, more light, better ventilation, etc. At the same time, the results of our analysis also point to the existence of a number of unintended consequences that leave workers worse off than before. Studies of stakeholders' perceptions of CSR reporting and compliance have already voiced concerns such as the increased financial burden on suppliers and the cosmetic nature of codes of conduct that leave substantial issues untouched (Belal and Roberts, 2010). Our three detailed cases presented in the previous section supply further evidence that those concerns indeed possess validity. Furthermore, by utilising an interdisciplinary analytical framework, the cases also demonstrate the depth of these issues, as well as that of the unintended consequences.

For example, while at face value workers now receive a higher minimum wage, due to the abolition of overtime their total monthly income is reduced. This leads to 
increased anxiety regarding their monthly rent payments and the ability to pay for the schooling of their children. Furthermore, workers still have to perform overtime to finish their often unrealistic daily quotas, but now without additional pay. This in turn leads to increased stress in the workplace. As a result of the high cost of compliance, the case firms had also been forced to discontinue services such as free cooked lunches and prayer facilities that had been highly valued by the workers. These are all examples of the destruction of previously existing social value, resulting in the impairment of social, economic, and cultural rights (Sinkovics et al., 2015). The cases also serve as an illustration of the prioritisation of prescribed needs over felt needs by compliance mechanisms (cf. Goldewijk and De Gaay Fortman, 1999). Moreover, similarly to the issue of child labour, where codes of conducts fail to take their rehabilitation and future welfare into account (cf. Belal and Roberts, 2010), in our cases there are no contingency plans for unskilled workers who have not only lost their jobs but are now excluded from the labour market.

Previous studies on the results of externally motivated CSR code compliance show similarly grim results. Taylor (2011) identifies three strategies based on the position of the supplier in a value chain. Higher-tier suppliers frequently adopt a high-road approach and substitute capital for labour as a way to generate greater productivity. In contrast, lower-tier suppliers tend to falsify the code of conduct processes and reports. Mid-tier suppliers strategically display a certain degree of compliance, mainly focusing on measurable outcomes while avoiding practices that threaten to reduce the power asymmetry vis-à-vis their employees. Our three cases belong to this latter category. The owners' motivation is best summarised by this quote from one of the interviews:

Compliance is like an ornamentation or decoration of our factory. Why do we prefer to buy the same product from supermarkets rather than traditional stores? It is because of the superior atmosphere in supermarkets. Compliance also enhances the beauty of our factories, in other words, the shopping environment for MNEs.

In a similar vein, Egels-Zandén (2007) finds that Chinese toy suppliers comply with just the formally monitored part of the code, such as codes on working hours, the minimum wage, child labour, employment contracts, and health and safety education. At the same time, they tend to marginalise issues related to workers' voice and bargaining power. They also, that study notes, pay limited attention to other process-oriented aspects of workers' rights. This is in line with the proposition of Barrientos and Smith (2007) that codes for labour practices are unlikely to challenge embedded labour relations, social discrimination, and other dominant social norms that underpin the production process.

The literature broadly suggests two distinct but related adoption patterns for CSR codes. Suppliers either adopt them reactively, because lead firms explicitly require them to do so (e.g. Locke, 2013), or proactively in the hope that compliance will allow them to enter a value chain and/or strengthen their position within one (Barin and Boehe, 2008; Taylor, 2011). In our cases, compliance was both externally imposed and used as a means of survival in the value chain. Our results furthermore indicate that the pressure to comply had also forced the case companies to upgrade economically. In all three cases, the manufacturers had invested in automated machines in order to make their processes more efficient and to be able to better adhere to the quality standards set by the buyers. It must be noted, however, that these investments had mostly been motivated by the fact that they could not afford to pay for workers' overtime. Process upgrading had furthermore been needed to generate the surplus necessary to
Rana Plaza collapse aftermath 
AAAJ

29,4

644

cover the cost of compliance. Hence, one could argue that, in these cases, economic upgrading had also been an unintended consequence of the compliance and auditing pressures experienced.

In line with Belal and Roberts (2010), Prieto-Carrón et al. (2006) argue that the current CSR initiatives of MNEs demonstrate a lack of understanding of the causes of poverty and the means of delivering actual benefits to workers and marginalised communities in developing countries. Newell (2008) takes the argument even further and argues that many corporations directly benefit from the poverty and misery of people and sometimes directly lobby for measures that will make matters worse for these vulnerable segments. As a consequence, many CSR initiatives happen in response to external pressures to restore or maintain legitimacy (cf. Belal and Owen, 2015; Scherer et al., 2013). Moreover, Taylor (2011) postulates that labour codes are often used as tools to succeed in the "politics of production". Lead firms can employ codes to maintain control over their suppliers (Ponte and Gibbon, 2005). As a consequence, suppliers are not only expected to satisfy the price and quality demands of MNE buyers, they also have to bear the high cost of compliance (Tencati et al., 2008). Against this background, suppliers are often forced to pursue profits at the cost of social value for their workers in order to survive and be able to compete (Taylor, 2008, 2011). This point is corroborated by our findings.

However, things are not always black and white, and in many cases the failure of standards and codes is not due to bad intentions but a lack of understanding of the root causes of certain problems (cf. Locke, 2013). To this end, Sinkovics et al. (2015) propose that, in order to construct accountability practices that go beyond addressing prescribed needs, it is crucial to take into consideration two sets of constraints: those that keep a given business from attaining its goals (firm survival and resilience) and those that keep the workers and their communities from attaining their goals (e.g. making use of their human rights). Only when the top-down approach (codes, agreements, and guiding principles) meets the bottom-up approach (needs and constraints) is it possible to go beyond mere symptom treatment and actually address social constraints. The cases in this study are a negative demonstration of this point.

From a social constraint perspective, the case companies originally displayed a certain degree of intrinsically motivated responsible behaviour vis-à-vis their workers. More specifically, they had mechanisms in place that enabled the realisation of certain social, economic, and cultural rights (e.g. the provision of lunch, a prayer room, etc.), which were subsequently destroyed by the imposition of external codes. Consequently, in order to safeguard existing responsible practices, a more flexible approach to accountability is needed, one that gauges the western conception of "good" labour practices (cf. Belal and Roberts, 2010) against the socially grounded needs (cf. Goldewijk and De Gaay Fortman, 1999) of workers, and at the same time considers the business constraints of the implementing actor (i.e. the supplier). Such an approach can be expected to yield more effective and meaningful interventions. This is also in line with the UN guiding principles stating that there should be a "meaningful consultation with potentially affected groups and other relevant stakeholders". Our study shows that suppliers can be a valuable source of information with regards to the improvement of workers' needs beyond "prescribed needs". As a consequence, multinational corporations' due diligence may need to be extended to a wider range of human rights including second-generation rights such as social, economic, and cultural rights.

While the present paper contributes to several bodies of literature, including critical accounting, CSR, human rights, GVC, and IB, due to its exploratory nature several 
limitations need to be acknowledged. The three case companies investigated here are small garment manufacturers with limited resources. Their primary motivation for the adoption of CSR standards is the hope that they can increase their competitiveness and attract more buyers. Due to their resource poorness, these firms have not been able to maintain their social-value-creating activities, even when they have wanted to. As a consequence, future research will need to investigate cases of suppliers that do have the resources to keep and/or extend previous initiatives. Moreover, larger scale studies will be needed to further explore, refine, and test the multi-system approach and the reconceptualised social value concept proposed by Sinkovics et al. (2015) and what this means for individual business models as well as for business models within GVCs and/or global production networks. Future research may also need to elaborate further on how this multi-system approach can aid the design and implementation of accounting and accountability practices, including with respect to the application of the UN guiding principles for business and human rights.

\section{References}

Accord (2015), "The Bangladesh Accord of fire and building safety", available at: www. bangladeshaccord.org/ (accessed 6 June 2015).

Barin, C.L. and Boehe, D.M. (2008), "CSR in the global marketplace", Management Decision, Vol. 46 No. 8, pp. 1187-1209.

Barrientos, S. and Kritzinger, A. (2004), "Squaring the circle: global production and the informalization of work in South African fruit exports", Journal of International Development, Vol. 16 No. 1, pp. 81-92.

Barrientos, S. and Smith, S. (2007), "Do workers benefit from ethical trade? Assessing codes of labour practice in global production systems", Third World Quarterly, Vol. 28 No. 4, pp. 713-729.

Barrientos, S., Gereffi, G. and Rossi, A. (2011), "Economic and social upgrading in global production networks: a new paradigm for a changing world", International Labour Review, Vol. 150 Nos 3-4, pp. 319-340.

Barrientos, S., Kritzinger, A., Opondo, M. and Smith, S. (2005), "Gender, work and vulnerability in African horticulture", IDS Bulletin, Vol. 36 No. 2, pp. 74-79.

bdnews24.com (2013), "RMG wage board prescribes hike", available at: http://bdnews24.com/ business/2013/11/04/rmg-wage-board-prescribes-hike (accessed 18 March 2014).

Belal, A. and Owen, D.L. (2015), "The rise and fall of stand-alone social reporting in a multinational subsidiary in Bangladesh: a case study", Accounting, Auditing \& Accountability Journal, Vol. 28 No. 7, pp. 1160-1192.

Belal, A.R. and Roberts, R.W. (2010), "Stakeholders' perceptions of corporate social reporting in Bangladesh", Journal of Business Ethics, Vol. 97 No. 2, pp. 311-324.

Belal, A.R., Cooper, S.M. and Khan, N.A. (2015), "Corporate environmental responsibility and accountability: what chance in vulnerable Bangladesh?", Critical Perspectives on Accounting, Vol. 33, December, pp. 44-58. doi: 10.1016/j.cpa.2015.01.005.

BGMEA (2014), “The ready made garment industry in Bangladesh", available at: www.bgmea. com.bd/home/about/AboutGarmentsIndustry (accessed 18 March 2014).

Brennan, N.M. and Solomon, J. (2008), "Corporate governance, accountability and mechanisms of accountability: an overview", Accounting, Auditing \& Accountability Journal, Vol. 21 No. 7, pp. 885-906.
Rana Plaza collapse aftermath 
AAAJ

29,4

646
BSCI (2014), "Overview of BSCI actions in Bangladesh”, Business Social Compliance Initiative, Brussels, available: http://old.bsci-intl.org/system/files/overview_of_bsci_actions_in_ bangladesh.pdf (accessed 19 April 2016).

Carnegie, G.D. (2014), "The present and future of accounting history", Accounting, Auditing \& Accountability Journal, Vol. 27 No. 8, pp. 1241-1249.

Clean Clothes Campaign (2013), "BSCI 10th anniversary shame over Rana Plaza", available at: www.cleanclothes.org/news/press-releases/2013/06/25/bsci-10th-anniversary-shame-overrana-plaza (accessed 21 April 2014).

Egels-Zandén, N. (2007), 'Suppliers' compliance with MNCs' codes of conduct: behind the scenes at Chinese toy suppliers", Journal of Business Ethics, Vol. 75 No. 1, pp. 45-62.

Eisenhardt, K.M. (1989), "Building theories from case study research", Academy of Management. The Academy of Management Review, Vol. 14 No. 4 pp. 532-550.

Financial Times (2013), "European retailors to sign Bangladesh safety pact", Financial Times, 14 May, available at: http://on.ft.com/12w9WAV (accessed 19 April 2015).

Forrester, J.W. (1968), Principles of Systems, Productivity Press, Cambridge, MA.

Gallhofer, S., Haslam, J. and van der Walt, S. (2011), “Accountability and transparency in relation to human rights: a critical perspective reflecting upon accounting, corporate responsibility and ways forward in the context of globalisation”, Critical Perspectives on Accounting, Vol. 22 No. 8, pp. 765-780.

Gereffi, G. (1999), "International trade and industrial upgrading in the apparel commodity chain", Journal of International Economics, Vol. 48 No. 1, pp. 37-70.

Gereffi, G. and Frederick, S. (2010), "The global apparel value chain, trade and the crisis: challenges and opportunities for developing countries", in Cattaneo, O., Gereffi, G. and Staritz, C. (Eds), Global Value Chains in a Postcrisis World: A Development Perspective, World Bank, Washington, DC, pp. 157-208.

Gereffi, G., Humphrey, J. and Sturgeon, T. (2005), "The governance of global value chains", Review of International Political Economy, Vol. 12 No. 1, pp. 78-104.

Giuliani, E. and Macchi, C. (2014), "Multinational corporations' economic and human rights impacts on developing countries: a review and research agenda", Cambridge Journal of Economics, Vol. 38 No. 2, pp. 479-517.

Goldewijk, B.K. and De Gaay Fortman, B. (1999), Where Needs Meet Rights: Economic, Social and Cultural Rights in a New Perspective, WSC Publications, Geneva.

Goldratt, E.M. (1990), What is this Thing Called Theory of Constraints and How Should it be Implemented? North River Press, Croton-on-Hudson, NY.

Gugler, P. and Shi, J.Y. (2009), "Corporate social responsibility for developing country multinational corporations: lost war in pertaining global competitiveness?", Journal of Business Ethics, Vol. 87 No. S1, pp. 3-24.

Guthrie, J. and Parker, L.D. (2014), "The global accounting academic: what counts!", Accounting, Auditing \& Accountability Journal, Vol. 27 No. 1, pp. 2-14.

Hoque, S.F., Sinkovics, N. and Sinkovics, R.R. (2016), "Supplier strategies to compensate for knowledge asymmetries in buyer-supplier relationships: implications for economic upgrading", European Journal of International Management, Vol. 10 No. 3, pp. 254-283.

Humphrey, C. and Scapens, R.W. (1996), "Methodological themes: theories and case studies of organizational accounting practices: limitation or liberation?", Accounting, Auditing \& Accountability Journal, Vol. 9 No. 4, pp. 86-106. 
Humphrey, J. and Schmitz, H. (2002), "How does insertion in global value chains affect upgrading in industrial clusters?", Regional Studies, Vol. 36 No. 9, pp. 1017-1027.

Islam, M.A. and Deegan, C. (2008), "Motivations for an organisation within a developing country to report social responsibility information: evidence from Bangladesh", Accounting, Auditing \& Accountability Journal, Vol. 21 No. 6, pp. 850-874.

Joannides, V. (2012), "Accounterability and the problematics of accountability", Critical Perspectives on Accounting, Vol. 23 No. 3, pp. 244-257.

Kabeer, N. and Mahmud, S. (2004), "Rags, riches and women workers: export-oriented garment manufacturing in Bangladesh", in Carr, M. (Ed.), Chains of Fortune: Linking Women Producers and Workers with Global Markets, Commonwealth Secretariat, London, pp. 133-162.

Kamuf, P. (2007), “Accounterability”, Textual Practice, Vol. 21 No. 2, pp. 251-266.

King, N. (2014), "Using templates in the thematic analysis of texts", in Cassell, C. and Symon, G. (Eds), Essential Guide to Qualitative Methods in Organizational Research, Sage Publications, London.

Labour Behind Label (2013), "Bangladesh building collapse kills over 1100 workers: Primark and Mango labels found", available at: www.labourbehindthelabel.org/urgent-actions/ item/1140-bangladesh-building-collapse-kills-over-80-workers-primark-and-mangolabels-found (accessed 18 April 2014).

Labowitz, S. and Baumann-Pauly, D. (2014), "Business as usual is not an option: supply chains and sourcing after Rana Plaza”, NYU Stern School of Business, New York, NY.

Lee, J. and Gereffi, G. (2015), "Global value chains, rising power firms and economic and social upgrading”, Critical Perspectives on International Business, Vol. 11 Nos 3/4, pp. 319-339. doi: 10.1108/cpoib-03-2014-0018.

Locke, R.M. (2013), The Promise and Limits of Private Power: Promoting Labor Standards in a Global Economy, Cambridge University Press, Cambridge and New York, NY.

London, T. and Hart, S.L. (2011), Next Generation Business Strategies for the Base of the Pyramid: New Approaches for Building Mutual Value, Pearson Education (distributor), FT Press, Upper Saddle River, NJ.

Lund-Thomsen, P. (2008), "The global sourcing and codes of conduct debate: five myths and five recommendations", Development \& Change, Vol. 39 No. 6, pp. 1005-1018.

McKernan, J.F. (2012), "Accountability as aporia, testimony, and gift", Critical Perspectives on Accounting, Vol. 23 No. 3, pp. 258-278.

McKernan, J.F. and McPhail, K. (2012), “Accountability and accounterability", Critical Perspectives on Accounting, Vol. 23 No. 3, pp. 177-182.

McKinsey (2011), "Bangladesh's readymade garments landscape: the challenge of growth", available at: www.mckinsey.de/sites/mck_files/files/2011_McKinsey_Bangladesh.pdf (accessed 20 April 2016; 11 September 2013).

Mashaw, J.L. (2005), "Structuring a 'dense complexity': accountability and the project of administrative law”, Issues in Legal Scholarship, Vol. 5 No. 1, pp. 1-38. doi: 10.2202/15398323.1061.

Newell, P. (2008), "CSR and the limits of capital", Development and Change, Vol. 39 No. 6, pp. 1063-1078.

Owen, D. (2008), "Chronicles of wasted time? A personal reflection on the current state of, and future prospects for, social and environmental accounting research", Accounting, Auditing \& Accountability Journal, Vol. 21 No. 2, pp. 240-267.

Parker, L.D. and Guthrie, J. (2014), "Addressing directions in interdisciplinary accounting research”, Accounting, Auditing \& Accountability Journal, Vol. 27 No. 8, pp. 1218-1226.
Rana Plaza collapse aftermath 
AAAJ

29,4

648
Pipkin, S. (2011), "Local means in value chain ends: dynamics of product and social upgrading in apparel manufacturing in Guatemala and Colombia”, World Development, Vol. 39 No. 12, pp. 2119-2131.

Ponte, S. and Gibbon, P. (2005), "Quality standards, conventions and the governance of global value chains", Economy and Society, Vol. 34 No. 1, pp. 1-31.

Prieto-Carrón, M., Lund-Thomsen, P., Chan, A., Muro, A. and Bhushan, C. (2006), "Critical perspectives on CSR and development: what we know, what we don't know, and what we need to know", International Affairs, Vol. 82 No. 5, pp. 977-987.

Reinecke, J. and Donaghey, J. (2015), "After Rana Plaza: building coalitional power for labour rights between unions and (consumption-based) social movement organisations", Organization, Vol. 22 No. 5, pp. 720-740.

Research Initiative for Social Equity Society (2014), “The Bangladesh labor law (amendment) bill 2013 passed in the parliament", available at: risebd.com/2013/07/16/the-bangladesh-laborlaw-ammendmend-bill-2013-passed-in-the-parliament/ (accessed 21 May 2015).

Rossi, A. (2011), "Economic and social upgrading in global production networks: the case of the garment industry in Morocco", doctoral thesis, University of Sussex, Brighton.

Rubenstein, J. (2007), “Accountability in an unequal world”, The Journal of Politics, Vol. 69 No. 3, pp. 616-632.

Scherer, A.G., Palazzo, G. and Seidl, D. (2013), "Managing legitimacy in complex and heterogeneous environments: sustainable development in a globalized world", Journal of Management Studies, Vol. 50 No. 2, pp. 259-284.

Sen, A. (1999), Development as Freedom, Knopf, New York, NY.

Sen, A. (2004), "Elements of a theory of human rights", Philosophy \& Public Affairs, Vol. 32 No. 4, pp. 315-356.

Sethi, S.P. (1975), "Dimensions of corporate social performance: an analytical framework", California Management Review (Pre-1986), Vol. 17 No. 3, pp. 58-64.

Sinkovics, N., Sinkovics, R.R. and Yamin, M. (2014), "The role of social value creation in business model formulation at the bottom of the pyramid - implications for MNEs?", International Business Review, Vol. 23 No. 4, pp. 692-707.

Sinkovics, N., Sinkovics, R.R., Hoque, S. and Czaban, L. (2015), "A reconceptualisation of social value creation as social constraint alleviation", Critical Perspectives on International Business, Vol. 11 Nos 3/4, pp. 340-363.

Sundar, P. (2013), Business and Community: The Story of Corporate Social Responsibility in India, Sage Publications, Los Angeles, CA.

Taylor, M. (2008), "Power, conflict and production of the global economy", in Taylor, M. (Ed.), Global Economy Contested: Power and Conflict Across the International Division of Labour, Routledge, London, pp. 11-31.

Taylor, M. (2011), "Race you to the bottom ... and back again? The uneven development of labour codes of conduct", New Political Economy, Vol. 16 No. 4, pp. 445-462.

Tencati, A., Russo, A. and Quaglia, V. (2008), "Unintended consequences of CSR: protectionism and collateral damage in global supply chains: the case of Vietnam", Corporate Governance: The International Journal of Business in Society, Vol. 8 No. 4, pp. 518-531.

Todaro, M.P. and Smith, S.C. (2011), Economic Development, 11th ed., Pearson Education Limited, Harlow.

Todaro, M.P. and Smith, S.C. (2015), Economic Development, 12th ed., Pearson, Harlow.

Tschakert, P. (2007), "Views from the vulnerable: understanding climatic and other stressors in the Sahel”, Global Environmental Change, Vol. 17 No. 3, pp. 381-396. 
Wettstein, F. (2012), "CSR and the debate on business and human rights: bridging the great divide”, Business Ethics Quarterly, Vol. 22 No. 4, pp. 739-770.

Zhu, S.J. and Pickles, J. (2014), "Bring in, go up, go west, go out: upgrading, regionalisation and delocalisation in China's apparel production networks", Journal of Contemporary Asia, Vol. 44 No. 1, pp. 36-63.

\section{About the authors}

Noemi Sinkovics is a Lecturer in International Business and Management at the Alliance Manchester Business School, UK. She received her $\mathrm{PhD}$ from the University of Manchester. Her research focuses on international entrepreneurship, ICT, and economic development issues and she contributes actively to research projects in the AMBS-CIBER. She has contributed book chapters to editions of International Business books and published in journals such as International Business Review, International Marketing Review, Journal of Business Research, Critical Perspectives on International Business, and European Journal of International Management. She is an Hungarian and now lives in Manchester, UK.

Samia Ferdous Hoque is a final year Postgraduate Research Student in International Business and Management at the Alliance Manchester Business School, UK. She obtained an MBA from the University of Bradford, UK. Her work is at the interface of interface of development literatures and IB, her specific context is the Bangladesh garment sectors.

Rudolf R. Sinkovics is a Professor of International Business at the Alliance Manchester Business School, UK, where he is currently the Director of the AMBS Centre for Comparative and International Business Research (CIBER) and AMBS Director of Research. He holds an Visiting Professorship at the Lappeenranta University of Technology in Finland. He has worked and published on inter-organisational governance, the role of ICT in firm internationalisation, and research methods in international business. Current work is on rising powers, and responsible business. He received his $\mathrm{PhD}$ from the Vienna University of Economics and Business (WU-Wien), Austria. His work has been published in international business and international marketing journals such as Journal of International Business Studies, Management International Review, Journal of World Business, International Business Review, and International Marketing Review. Born in Austria, he now lives and works in Manchester, UK. Rudolf R. Sinkovics is the corresponding author and can be contacted at: rudolf.sinkovics@manchester.ac.uk
Rana Plaza collapse aftermath

For instructions on how to order reprints of this article, please visit our website:

www.emeraldgrouppublishing.com/licensing/reprints.htm

Or contact us for further details: permissions@emeraldinsight.com 